\title{
Macroeconomic effects of fiscal adjustment: A tale of two approaches
}

\author{
Weonho Yang, Jan Fidrmuc *, Sugata Ghosh \\ Department of Economics and Finance, Brunel University, Uxbridge, UK
}

\section{A R T I C L E I N F O}

\section{Article history:}

Available online 24 June 2015

JEL Classification:

E13

E22

E62

\section{Keywords:}

Fiscal policy

Fiscal adjustment

Narrative approach

Cyclically adjusted primary balance

\begin{abstract}
A B S T R A C T
We investigate the short-term effects of fiscal adjustment on economic activity in 20 OECD countries from 1970 to 2009. We compare two approaches: the traditional approach based on changes in cyclically adjusted primary balance (CAPB) and the narrative approach based on historical records. Proponents of the latter argue that it captures discretionary fiscal adjustment more accurately than the traditional approach. We propose a new definition of CAPB that takes account of fluctuations in asset prices and reflects idiosyncratic features of fiscal policy in individual countries. Using this new definition, we find that fiscal adjustments always have contractionary effects on economic activity in the short term; we find no evidence of expansionary (non-Keynesian) fiscal adjustments. Spending-based fiscal adjustments lead to smaller output losses than tax-based fiscal adjustment. These results are in line with the literature using the narrative approach, suggesting that the CAPB, when correctly specified, can be used as a measure of fiscal adjustments.
\end{abstract}

(c) 2015 The Authors. Published by Elsevier Ltd. This is an open access article under the CC BY license (http:// creativecommons.org/licenses/by/4.0/).

\footnotetext{
We benefited from comments and suggestions received from seminar and conference participants at Durham University, Slovak National Bank, Royal Economic Society conference 2014, CESifo Area Conference on Macro, Money and International Finance 2014, BMRC conference 2014 and the ZEW Public Finance Conference 2015. Weonho Yang's research on this paper was supported by a partial PhD scholarship from the Ministry of Strategy and Finance of the Republic of Korea, whose generosity he would like to gratefully acknowledge.

* Corresponding author. Tel.: +44 1895266528.

E-mail address: Jan.Fidrmuc@brunel.ac.ukjan@fidrmuc.net or (J. Fidrmuc). http://dx.doi.org/10.1016/j.jimonfin.2015.05.003 0261-5606/@ 2015 The Authors. Published by Elsevier Ltd. This is an open access article under the CC BY license (http:// creativecommons.org/licenses/by/4.0/).
} 


\section{Introduction}

The recent global economic and financial crisis and the associated fiscal austerity in the Eurozone and elsewhere have resulted in a renewed interest in the relationship between fiscal reform and economic growth. Although there is widespread agreement that reducing public deficits and debt has important benefits in the long term, there is less of a consensus regarding the short-term effects of fiscal adjustment. In part, this is because of the oft-quoted examples of Denmark and Ireland, which experienced improved growth performance after periods of strict fiscal austerity in the $1980 \mathrm{~s} .{ }^{1}$ Their experience defies the conventional Keynesian theory which predicts negative short-run economic effects of restrictive fiscal policy. Subsequently, Giavazzi and Pagano (1990), Alesina and Perotti (1997), Alesina and Ardagna $(1998,2010)$ and others sought to find other examples of such expansionary fiscal adjustments and argued that fiscal adjustment can stimulate economic growth even in the short term, in a phenomenon referred to as 'Non-Keynesian effects' or 'expansionary fiscal contraction'.

Typically, the empirical studies seeking evidence of expansionary fiscal adjustments rely on observing changes in the cyclically adjusted primary balance (CAPB). The CAPB is an indicator that captures discretionary fiscal policy and other noncyclical factors by excluding the automatic effects of business cycle fluctuations (through transfers, taxes and interest payments) on the budget. ${ }^{2}$ However, Guajardo et al. (2014) criticize this approach on the grounds that using the CAPB can yield misidentified fiscal adjustment episodes. In particular, they argue that improvements in the CAPB due to stock-market booms and/or one-off fiscal revenues can be misclassified as fiscal reforms. They favor a narrative approach, based on careful study of historical documents to identify fiscal adjustments episodes. Applying this to a sample of OECD countries, they fail to identify any expansionary fiscal adjustments.

In this paper, we build on and extend the work of Guajardo et al. (2014). We consider 20 OECD countries so that our scope is similar to that of their paper. In contrast to their approach, we use the CAPB instead of the narrative approach. However, we modify the CAPB to take account of the problems that Guajardo et al. (2014) point out. In particular, we construct the CAPB measure so that it reflects fluctuations in asset prices and takes into account the heterogeneity of fiscal policy across countries. Using this new measure of fiscal adjustment, we obtain results that are very similar to those that Guajardo et al. (2014) obtain with the narrative approach. With our modified CAPB measure, we find no evidence of Non-Keynesian effects. Nevertheless, our results confirm that spending-based fiscal adjustments have more beneficial macroeconomic effects than tax-based fiscal adjustments, which is in line with the previous theoretical and empirical evidence.

This paper is organized as follows. Section 2 reviews the theoretical and empirical literature on the effects of fiscal adjustments. In section 3, we explain our new measure to identify fiscal adjustments and list the fiscal adjustment episodes that we identify. Section 4 outlines the empirical framework and presents the results. Section 5 examines the robustness of our results. Finally, section 6 concludes.

\section{Related literature}

\subsection{Theory}

There is a general agreement that fiscal consolidation and the resulting reduced government debt contribute to long-run economic growth. However, there is disagreement about the short-term effect. Keynesian economics predicts that a cut in government spending or an increase in taxes reduces the aggregate demand and income directly, which leads to negative multiplier effects on the output in the short term. As a result, government debt to output ratio may not be reduced much or at all because both output and tax revenues fall due to the contractionary effects of the fiscal adjustment.

\footnotetext{
1 According to Giavazzi and Pagano (1990), the sharp fiscal contractions (primary fiscal deficit reduction equal to 10\% of GDP in Denmark during 1983-1986 and 7\% of GDP in Ireland during 1987-1988 were accompanied by average real growth of 3.6\% and $3.7 \%$, respectively.

2 The CAPB is calculated by taking the actual primary balance (balance minus net-interest payment) and subtracting the estimated effects of business cycles on the budget.
} 
In contrast, Neoclassical economics predicts that fiscal adjustments can stimulate the economy with an increase in private consumption and investment through several transmission mechanisms even in the short term. These mechanisms entail both demand and supply side effects. First, on the demand side, wealth effects or credibility effects are suggested to be at work. Blanchard (1990) proposes a model in which consumers react to two kinds of effects. One is the intertemporal tax redistribution effect by non-Ricardian agents in a Keynesian model where an increase in taxes decreases consumption. The other is due to distortionary effects of taxes, whereby an increase in taxes eliminates the need for a larger and more disruptive adjustment in the future. As a result, people can expect an increase in their permanent income due to the future reduction in the deadweight loss, and therefore consume more. Blanchard argues that if people exhibit little myopia and the fiscal adjustment is made from a high debt level, consumption can react positively. Bertola and Drazen (1993) present an optimizing model and demonstrate that if a change of fiscal policy induces sufficiently strong expectation of future policy change in the opposite direction, it can give rise to a nonlinear relationship between private consumption and government spending. If a cut in government spending induces expectation of significantly lower future taxes, it may induce an increase in the current private consumption.

Similarly, Sutherland (1997) links current fiscal policy and future expected taxes. His model emphasizes the dynamics of government debt and considers consumers with finite horizons. At low levels of debt, fiscal policy has the usual Keynesian effects because people expect the debt stabilization program as something distant from their perspective. On the other hand, at high levels of debt, as a major fiscal consolidation is imminent, people react to government spending in a nonKeynesian way, expecting that they will have to pay more taxes shortly. Therefore, fiscal adjustment can give rise to positive wealth expectation effects when it occurs under high and rapidly growing debt-to-GDP ratio.

Other mechanisms include credibility effects, whereby fiscal adjustment reduces the default and inflation risk via the decline in interest rates (Feldstein, 1982). When a high level of government debt affects the interest rate risk premium, a reliable fiscal adjustment can reduce the premium and, in turn, the reduction of interest rate raises permanent income. In addition, lower interest rate can also lead to the appreciation of financial assets which triggers higher consumption and investment. Expansionary fiscal adjustment may take place also on the supply side via the labor market and investment (Alesina et al., 2002, 2008). If fiscal adjustment takes the form of a cut in public spending, especially in the area of public employment, rather than an increase in taxes, it can lead to a reduction of overall wage pressure in the economy and stimulate private employment and investment.

\subsection{Empirical considerations}

There is a large empirical literature seeking to find evidence of expansionary fiscal adjustments (non-Keynesian effects) since Giavazzi and Pagano (1990) suggested, based on the examples of Denmark and Ireland in the 1980s, that large and decisive fiscal adjustment can increase private consumption. Fiscal adjustment is usually identified as an improvement of CAPB in excess of a chosen threshold over a given period. Two aspects of fiscal adjustments receive attention: the factors that ensure that fiscal adjustments are expansionary or successful, and the effects of fiscal adjustments on macroeconomic outcomes.

The studies interested in the former classify the episodes according to the definition of expansionary or successful fiscal adjustment ${ }^{3}$ and then perform a descriptive analysis of the characteristics of fiscal components and other related macroeconomic variables such as GDP and interest rate before, during, and after the fiscal adjustment period (Alesina and Ardagna, 1998, 2010, 2012; Alesina and Perotti, 1995, 1997; Giudice et al., 2007; McDermott and Wescott, 1996). These studies tend to find that fiscal consolidations based on spending cuts rather than on tax increases are more likely to be both expansionary and successful. Other papers use binary dependent variable models such as logit or probit to analyze which factors determine the success of fiscal consolidations (Afonso et al., 2006;

\footnotetext{
${ }^{3}$ Following Alesina and Ardagna (2012), we consider a fiscal adjustment to be successful if it brings about a sustained reduction in the debt-to-GDP ratio, and expansionary, if it is followed by positive economic growth.
} 
McDermott and Wescott, 1996) and their expansionary effects (Alesina and Ardagna, 1998; Giudice et al., 2007). McDermott and Wescott (1996) argue that the success in reducing the debt ratio depends on the size and composition of fiscal adjustment. They show that fiscal adjustments based on spending cuts are more likely to be successful than tax-based ones. Furthermore, the greater the magnitude of fiscal adjustment, the more likely it is to succeed. On the other hand, they show that fiscal adjustments are more likely to fail during a global recession. Afonso et al. (2006) assess fiscal consolidations in Central and Eastern European countries and suggest that spending-based adjustments were more successful. Giudice et al. (2007), finally, conclude that fiscal consolidation is more likely to promote economic growth during periods of below potential output and when the fiscal adjustment is based on spending cuts.

The latter focus (on macroeconomic effects of fiscal adjustments) is less common. Using panel data of industrial and developing countries, Giavazzi et al. (2000) analyze the relationship between fiscal policy and national savings and conclude that their relationship can be nonlinear when the fiscal impulse is sufficiently large and persistent, similar to the previous studies on fiscal policy and private consumption (Giavazzi and Pagano, 1990, 1996). Ardagna (2004) studies the determinants and channels through which fiscal adjustment affect growth. She shows that whether a fiscal adjustment is expansionary depends largely on the composition of fiscal policy, and that spending cuts can lead to higher growth rates via the labor market rather than through agents' expectation. On the other hand, Burger and Zagler (2008) analyze the relation between U.S. growth and fiscal adjustments in the 1990s and argue that non-Keynesian effects prevail through an increase in consumption because of improved consumer confidence and an increase in investment via the labor market and financial market. Afonso (2010) assesses expansionary fiscal adjustment in European countries and finds that fiscal consolidations tend to have long-term expansionary effects, but no significant effects in the short-run. Thus, although there are some differences among these empirical studies in the factors affecting expansionary fiscal adjustment such as the size, composition and the initial conditions, overall, the empirical literature based on fiscal adjustment episodes identified by the changes in the CAPB supports the existence of non-Keynesian effects.

Several papers, however, take issue with the results of the aforementioned CAPB-based studies. First, they argue that the results can be plagued by selection bias, measurement error, spurious correlation, or simultaneity issues when identifying fiscal consolidation episodes. Using the same panel data as Giavazzi et al. (2000), Kamps (2006) challenges their finding that non-Keynesian effects are a general and easily exploitable phenomenon by showing that the nonlinear effect disappears when crosscountry heterogeneity is taken into account. Park and Song (2010) and Hernández de Cos and Moral-Benito (2011) raise the possibility of endogeneity of the fiscal consolidation decision and find that fiscal adjustments have negative effects on GDP when taking this into account.

In line with these criticisms, IMF (2010), Guajardo et al. (2014) and Devries et al. (2011) suggest an alternative way of identifying fiscal consolidations instead of using the CAPB. Their approach is based on reviewing historical documents, similar to Romer and Romer (2010), to identify discretionary fiscal changes motivated by the desire to reduce the budget deficit. They then compare their episodes with those of Alesina and Ardagna (2010) and show that the episodes identified using historical data have contractionary effects on GDP, while the CAPB-based episodes are associated with a rise in GDP. Hence, using the CAPB is likely to be biased in favor of non-Keynesian effects.

The narrative literature, furthermore, identifies a number of problems related to using the CAPB. First, using a statistical concept such as the CAPB can be marred by non-policy related developments such as booms or contractions in the stock market. ${ }^{4}$ Second, the CAPB-based method is likely to ignore the motivation behind fiscal changes. For example, the rise of CAPB can be aimed at restraining economic overheating, not at reducing the budget deficit. ${ }^{5}$ In addition, it can omit some episodes of fiscal

\footnotetext{
4 They provide an example of Ireland in 2009 when a recession-induced collapse in stock and house prices led to a decrease of CAPB in 2009 in spite of the on-going fiscal consolidation.

${ }^{5}$ For example, in responding to the rapid domestic demand growth in Finland in 2000, the government adopted a spending cut to stabilize the economy.
} 
adjustment followed by an adverse shock and discretionary fiscal stimulus. ${ }^{6}$ Third, the CAPB data cannot exclude some cases of offsetting positive changes in the CAPB caused by large one-off accounting operation in the previous year that are unrelated to fiscal adjustment measures, such as the capital transfers of Japan in 1998 and the Netherlands in 1995. ${ }^{7}$ Based on their new dataset, they conclude that fiscal adjustments have contractionary effects on economic activity, and argue that large spending-based fiscal consolidations cannot be expansionary. On the other hand, Alesina and Ardagna (2012) reestimate the effect with new episodes identified based on the persistence of CAPB changes rather than on their size. They make a somewhat intermediate conclusion that spending-based adjustments cause smaller recessions than tax-based ones. They also argue that an expansionary fiscal adjustment is possible when it is combined with accommodating monetary policy.

Last but not least, fiscal adjustments may affect the economic activity and vice versa. Countries are more likely to consider implementing fiscal adjustment to reduce the debt-to-GDP ratio when they are experiencing relatively favorable economic growth. Therefore, expansionary fiscal adjustments can be the result of self-selection and the decision to implement a fiscal adjustment is endogenous. ${ }^{8}$ Moreover, as many theoretical studies argue, if wealth effects and expectations are the main channels by which the fiscal adjustments affect economic activity, the episodes identified by the narrative approach based upon announced plans for deficit cuts can capture the fiscal adjustments and their effects better and more correctly than those identified by the CAPB based on actual fiscal outcomes.

The main upshot of the preceding discussion is that while the narrative approach seems superior in identifying fiscal adjustment correctly, ${ }^{9}$ using the CAPB has the advantage in its simple and easy application. Therefore, if the construction of the CAPB could be improved to reflect the problems pointed out by the narrative approach, the CAPB could be a useful indicator of fiscal policy. That is what we set out to do in the remainder of the paper.

\section{Data and identification of fiscal adjustment episodes}

\subsection{Data}

We use an unbalanced panel of OECD countries covering the period from 1970 to 2009. All fiscal and macroeconomic data are obtained from the OECD Economic Outlook No.88. ${ }^{10}$ The sample includes 20 countries for which we have data for 20 years or more: Australia, Austria, Belgium, Canada, Denmark, Finland, France, Germany, Ireland, Italy, Japan, Korea, Netherlands, New Zealand, Norway, Portugal, Spain, Sweden, United Kingdom, and United States.

To identify the instances of discretionary fiscal adjustment, we use cyclically adjusted primary fiscal variables. In particular, we use primary fiscal variables which exclude interest payments because the fluctuations in interest payments cannot be regarded as discretionary. To make the cyclical correction, we follow the method proposed by Blanchard (1993) and used also by Alesina and Perotti (1995, 1997) and Alesina and Ardagna (1998, 2010, 2012). It is simpler and more transparent than the more

\footnotetext{
${ }^{6}$ An example is Germany in 1982: although deficit reduction was implemented in 1981, countercyclical stimulus measures were introduced in 1982 because of a sudden recession.

7 For example, the one-time capital transfers to the Japan National Railway in Japan in 1998 and to the social housing subsidy in Netherlands in 1995 caused large increases in the CAPB in the following years.

8 See Riera-Crichton et al. (2012) for an extensive discussion of the endogeneity of fiscal policy and measures to counter this. The authors distinguish between two issues: the identification of exogenous fiscal (tax) policy shocks (i.e., those which are not the outcome of policymakers' response to output fluctuations) and the measurement of tax policy (which is under the direct control of the policymaker). To this end, they construct a novel value-added tax rate data-set for 14 industrial countries for the 1980-2009 period. They use these data to overcome endogeneity problems, which could arise because (i) tax revenues constitute a policy outcome, increasing (decreasing) during booms (recessions), and (ii) policymakers typically pursue contractionary (expansionary) fiscal policy during booms (recessions).

${ }^{9}$ The findings of Riera-Crichton et al. (2012) offer support to the notion that the narrative approach is appropriate for identifying truly exogenous fiscal shocks (more so than the SVAR). The authors show that if information obtained from the narrative approach is incorporated into SVAR estimations, then the resulting tax multipliers are more contractionary than the standard SVAR estimates.

${ }^{10}$ More recent OECD Economic Outlooks cover a more limited period.
} 
complicated official measures such as those of the OECD and IMF which utilize estimates of potential output and fiscal multipliers (Alesina and Ardagna, 1998, 2010). The basic principle of this method is that since the government spending depends negatively on GDP due to unemployment benefits and the revenues respond positively to GDP due to tax receipts, the changes in the cyclically adjusted fiscal variables can be calculated from the difference between the predicted current-year value (which would prevail if unemployment had not changed since the previous year) and the actual value in the previous year. ${ }^{11}$

The CAPB, however, can also be affected crucially by changes in asset prices. For example, a stock market boom can increase the cyclically-adjusted tax revenues because of capital gains taxes as well as increased tax receipts due to higher private consumption and investment. As identified by Guajardo et al. (2014), such measurement error, i.e., the correlation between the change in the CAPB and the error term (in the regression capturing the effect of fiscal policy on economic activity) is likely to be positive, and this could downplay the contractionary effects of fiscal consolidation in using the CAPB. Among other studies that highlight the importance of asset price changes to fiscal policy outcomes, Morris and Schuknecht (2007) find that stocks and real estate wealth, which account for a significant share of household and corporate wealth and whose value can change considerably over a relatively short period of time, are particularly relevant for tax receipts. ${ }^{12}$ Tagkalakis (2011a, 2011b) also finds that financial markets have a significant impact on the fiscal positions and suggests that higher asset prices improve fiscal balances and contribute to initiating a successful fiscal adjustment. ${ }^{13}$

Therefore, we use a share price index as an additional variable determining the CAPB. ${ }^{14}$ The impact on fiscal balance, especially tax revenues, can be different according to the types of asset price and tax systems (Morris and Schuknecht, 2007; Tagkalakis, 2011a). Therefore, when considering asset price variables as a business cycle factor, it would be ideal to include other types of asset prices such as equities and property prices. We use only the share price index due to data availability and its particular relevance to tax revenues. This can be deemed a limitation of our methodology, but we believe this index is representative of the other asset price movement. ${ }^{15}$

Our measure of the changes in the CAPB is constructed following Alesina and Ardagna (1998). First, to get the cyclically adjusted spending as a ratio to GDP, we regress primary spending on a time trend and the unemployment rate $\left(U_{t}\right)$ for each country in the sample:

$$
G_{t}=\alpha_{0}+\alpha_{1} \text { Trend }+\alpha_{2} U_{t}+e_{t}
$$

\footnotetext{
${ }^{11}$ As an additional robustness check, we also use the output gap instead of unemployment to cyclically adjust government spending and revenue. These results are presented in section 5.1 .

12 The authors estimate short- (and where relevant) long-term elasticities for four revenue categories (direct taxes on corporations, direct taxes on households, indirect taxes, and taxes on financial transactions) with respect to equity and residential property prices for 16 OECD countries, including 11 EU Member States. Their empirical analysis points to significant and positive asset price effects for all four revenue categories for most countries in the sample. The impact of asset prices seems to be strongest on transactions taxes and on corporate taxes, while the effects on direct household taxes and indirect taxes tend to be smaller. However, given the greater importance of the latter two revenue categories, asset price effects on all four categories seem capable of giving rise to notable budgetary effects. See also Price and Dang (2011), who present econometric estimates of tax revenue elasticities measuring the response of the major tax categories to house-price and equity-price movements.

13 Other studies that show that the financial market variables have significant impact on fiscal primary balance, particularly through government revenues, include Eschenbach and Schuknecht (2002), Tujula and Wolswijk (2007), Reinhart and Rogoff (2009), and Tagkalakis (2012).

${ }^{14}$ A very recent study by Ardanaz et al. (2015), based on an original dataset comprising 20 Latin American and Caribbean countries, presents estimates of structural fiscal balances in their sample, and attempts to measure the degree of estimation uncertainty around estimates of the CAPB. This uncertainty arises since the standard formula requires estimation of unobserved variables (potential output and the corresponding output gap) and parameters (tax and spending elasticities). Furthermore, Ardanaz et al. (2015) make use of information on output that was available at the time that fiscal policy decisions were made. The authors find large differences between theirs and the traditional methods and therefore feel that caution in the use of CAPB seems warranted.

${ }^{15}$ For robustness, we use the house price index instead of the share price index, although the number of observations gets smaller. The results, reported in the section on robustness, are very similar.
} 
Then, with the estimated coefficients $\left(\hat{\alpha}_{1}, \hat{\alpha}_{2}\right)$ and the preceding-year unemployment rate $\left(U_{t-1}\right)$, we calculate the value of primary spending adjusted for changes in unemployment:

$$
G_{t}^{*}\left(U_{t-1}\right)=\hat{\alpha}_{0}+\hat{\alpha}_{1} \text { Trend }+\hat{\alpha}_{2} U_{t-1}
$$

The changes in discretionary spending are calculated as $G_{t}^{*}\left(U_{t-1}\right)-G_{t-1}$. A similar procedure is applied to compute the cyclically adjusted revenues. However, this time, the asset price index is added to the regression.

$$
\begin{aligned}
& \mathrm{R}_{\mathrm{t}}=\alpha_{0}+\alpha_{1} \text { Trend }+\alpha_{2} \mathrm{U}_{\mathrm{t}}+\alpha_{3} \text { Assetprice }_{\mathrm{t}}+\mathrm{e}_{\mathrm{t}} \\
& R_{t}^{*}\left(U_{t-1}, \text { Assetprice }_{t-1}\right)=\hat{\alpha}_{0}+\hat{\alpha}_{1} \text { Trend }+\hat{\alpha}_{2} U_{t-1}+\hat{\alpha}_{3} \text { Assetprice }_{t-1}
\end{aligned}
$$

Finally, the changes in discretionary fiscal policy are obtained as follows

$$
\Delta C A P B=\left[R_{t}^{*}-R_{t-1}\right]-\left[G_{t}^{*}-G_{t-1}\right]
$$

Guajardo et al. (2014) criticize the CAPB using the example of Ireland in 2009. In that instance, the CAPB to GDP ratio, used by Alesina and Ardagna (2010), fell because of the decline in tax receipts due to the sharp fall in stock and house prices. They argue that this shows the inaccuracy of the CAPB, as the Irish government was implementing austerity reform at the time. Indeed, our new measure that takes account of the fluctuations in asset price has the Irish CAPB improving by $1.3 \%$ of GDP in 2009.

\subsection{Definition of fiscal adjustment}

The literature identifies fiscal adjustment episodes as large and lasting changes in the CAPB. Table 1 summarizes the definitions used in the literature: the criteria of size and persistence are considerably different across the various studies, and even a little arbitrary. In addition, although different studies

\begin{tabular}{|c|c|}
\hline Study & Criteria for the change in the improvement of CAPB \\
\hline $\begin{array}{l}\text { Alesina and Perotti (1995), Alesina and } \\
\text { Ardagna (2010) }\end{array}$ & The change is at least $1.5 \% \mathrm{p}$ of GDP in 1 year \\
\hline Alesina and Perotti (1997) & $\begin{array}{l}\text { The change is at least } 1.5 \% \mathrm{p} \text { of GDP in } 1 \text { year or at least } 1.25 \% \mathrm{p} \text { of GDP per } \\
\text { year in both two consecutive years }\end{array}$ \\
\hline McDermott and Wescott (1996) & $\begin{array}{l}\text { The change is at least } 1.5 \% \mathrm{p} \text { of GDP over } 2 \text { years with the improvement of } \\
\text { each year }\end{array}$ \\
\hline $\begin{array}{l}\text { Alesina and Ardagna (1998), Giudice } \\
\text { et al. (2007), Ardagna (2004) }\end{array}$ & $\begin{array}{l}\text { The change is at least } 2 \% \mathrm{p} \text { of GDP in } 1 \text { year or at least } 1.5 \% \mathrm{p} \text { of GDP per year in } \\
\text { both } 2 \text { consecutive years }\end{array}$ \\
\hline Alesina and Ardagna (2012) & $\begin{array}{l}\text { The cumulative change is at least } 2 \% \mathrm{p} \text { of GDP in } 2 \text { consecutive years and at } \\
\text { least } 3 \% \mathrm{p} \text { of GDP in } 3 \text { or more years with the improvement of each year }\end{array}$ \\
\hline Giavazzi and Pagano (1996) & $\begin{array}{l}\text { The cumulative change is at least } 5,4,3 \% \text { p of GDP in respectively } 4,3 \text {, or } 2 \\
\text { consecutive years, or } 3 \% \text { p in } 1 \text { year }\end{array}$ \\
\hline Giavazzi et al. (2000), Kamps (2006) & The change is at least $1.5 \% \mathrm{p}$ of GDP per year over 2 consecutive years \\
\hline Afonso et al. (2006) & $\begin{array}{l}\text { The change is above the average }+2 / 3 \text { times the standard deviation for all } \\
\text { discretionally changes of budget balance in the entire sample }\end{array}$ \\
\hline $\begin{array}{l}\text { Ahrend et al. (2006), Guichard et al. } \\
\text { (2007) }\end{array}$ & $\begin{array}{l}\text { - Starts if the change is at least } 1 \% \mathrm{p} \text { of potential GDP in } 1 \text { year or in } 2 \\
\text { consecutive years with at least } 0.5 \% \text { p in the first of the two years. } \\
\text { - Continues as long as the CAPB improves or deteriorates at most } 0.3 \% \mathrm{p} \text { of } \\
\text { GDP but is offset in the following year. } \\
\text { - Terminates if the CAPB stops increasing or improves by less than } 0.2 \% \mathrm{p} \text { of } \\
\text { GDP in one year and then deteriorates. }\end{array}$ \\
\hline
\end{tabular}
impose different thresholds, the same threshold is always applied to all countries. In other words, they

Table 1

Definitions of fiscal adjustment. 
do not allow for country-specific heterogeneity in discretionary fiscal shocks and the private sector responses to them. Since the expectations and confidence of the private sector are key factors for the transmission of fiscal shocks, past fiscal record should be considered. For example, for a country which has seldom experienced large changes in discretionary fiscal policy, a small fiscal adjustment can send a strong signal of the government's willingness to reduce the budget deficit. However, for a country that has had large fluctuations of fiscal policy in the past, a similarly sized fiscal adjustment can prove insufficient to elicit any response from the private sector. For example, while Burger and Zagler (2008) and Guajardo et al. (2014) identify several fiscal adjustment episodes in the U.S., Alesina and Ardagna $(2010,2012)$ identify none for that country. Therefore, one should consider the idiosyncrasy of fiscal policy in each country. For this reason, we base our definition of fiscal adjustment on the countryspecific average $\left(\mu_{i}\right)$ and standard deviations $\left(\sigma_{i}\right)$ of the changes in the CAPB.

Our definition for identifying fiscal adjustment episodes has 4 criteria, incorporating size, persistence and country-specific heterogeneity, as follows:

1 A fiscal adjustment occurs in a given year if the CAPB improves by at least the average $\left(\mu_{\mathrm{i}}\right)+$ standard deviation $\left(\sigma_{\mathrm{i}}\right)$ in that year.

2 A fiscal adjustment takes place over a period of multiple years when the CAPB improves by at least $\mu_{\mathrm{i}}+1 / 3 \sigma_{\mathrm{i}}$ in the first year and the cumulative change is at least $\mu_{\mathrm{i}}+4 / 3 \sigma_{\mathrm{i}}$ over 2 years or $\mu_{\mathrm{i}}+2 \sigma_{\mathrm{i}}$ over 3 or more years.

3 A spell of fiscal adjustment terminates if the CAPB improves by less than $\mu_{\mathrm{i}}+1 / 3 \sigma_{\mathrm{i}}$ or deteriorates in one year, except when the change in the CAPB is between $\mu_{i}+1 / 3 \sigma_{i}$ and $\mu_{i}-1 / 3 \sigma_{i}$ in that year, and the cumulative change over the following year is an improvement of at least $\mu_{\mathrm{i}}+1 / 3 \sigma_{\mathrm{i}}$.

4 A fiscal adjustment does not occur in a given year if the CAPB improves by at least $\mu_{\mathrm{i}}+\sigma_{\mathrm{i}}$ in that year, but in the previous or following year, the CAPB worsens by over $\mu_{\mathrm{i}}+\sigma_{\mathrm{i}}$.

These criteria are chosen for the following reasons. First, as already explained, the different cutoff values reflect the heterogeneity of each country's fiscal policy, as embodied in the average $\left(\mu_{\mathrm{i}}\right)$ and standard deviation $\left(\sigma_{\mathrm{i}}\right)$ of the changes in the CAPB: the standard deviation $\left(\sigma_{\mathrm{i}}\right)$ during 1970-2009 ranges from $3.73 \%$ of GDP in Norway to $0.88 \%$ in the U.S. Second, the 3rd criterion ensures that episodes when the CAPB improves little or deteriorates temporarily, but are offset in the following year, are also counted. Third, the 4th criterion excludes sharp increases in the CAPB due to one-off accounting operations such as one-time capital transfers. As in the other studies, there is also an element of arbitrariness in our definition, in particular in choosing the multiples $(1,1 / 3,4 / 3,2)$ of standard deviation. In the robustness section, we use alternative rules and thresholds in order to check whether the results are sensitive to these values.

According to our definition, we identify 199 instances of fiscal adjustment in 20 OECD countries from 1970 to 2009. These consist of 66 distinct episodes, as summarized in Table 2 and Figs. 1 and $2 .{ }^{16}$ These episodes include only those that led to a sufficiently large improvement in the CAPB. This list includes several well-known episodes such as Denmark (84-86) and Ireland (82-84, 86-88). Importantly, the episodes that are used by Guajardo et al. (2014) to illustrate the discrepancies between the two approaches are identified correctly. ${ }^{17}$

Note that applying country-specific thresholds for identifying fiscal adjustments need not necessarily imply that the thresholds are generally lower. When we use Alesina and Ardagna's (2012) definition of fiscal adjustment but account for the stock market, this results in identifying fewer episodes for some countries but more episodes for others (results available upon request).

\footnotetext{
${ }^{16}$ Multi-year fiscal adjustment is regarded as a single episode following Alesina and Ardagna (2012) because fiscal adjustments often are multi-year processes. Moreover, it is very difficult to distinguish the episodes and correct timing during years of long-lasting improvement of the CAPB. We also introduced each modification separately (we are grateful to an anonymous referee for suggesting this). The list of episodes obtained in this way is available upon request. The three lists overlap to a large extent. In most cases, implementing only one modification results in fewer episodes being identified, except in the cases of Ireland, Italy, Korea and Netherlands.

17 Our list includes the episodes of Germany (1982) and Italy (1993), but excludes the episodes of Finland (2000), Germany (1996), Japan (1999), and Netherlands (1996) just as Guajardo et al. (2014).
} 
Table 2

Episodes of fiscal adjustment.

\begin{tabular}{llcc}
\hline Country (sample period) & Period & No. episodes & No. years \\
\hline Australia (70-09) & $77-80,82-83,86-88,91-93,96-98$ & 5 & 15 \\
Austria (70-09) & $77-81,84,96-97,01,05-07$ & 5 & 12 \\
Belgium (86-09) & $87,93-98$ & 2 & 7 \\
Canada (70-09) & $81-83,86-87,91-97$ & 3 & 12 \\
Denmark (83-09) & $84-86,03-05$ & 2 & 6 \\
Finland (70-09) & $76-77,92-94,96$ & 3 & 6 \\
France (80-09) & $83-87,94,96-99,04-06$ & 4 & 13 \\
Germany (70-09) & $82-85,92-94,97-00,03-07$ & 4 & 16 \\
Ireland (70-09) & $75-77,82-88$ & 2 & 10 \\
Italy (70-09) & $82-83,86-88,92-97$ & 3 & 11 \\
Japan (70-09) & $79-87,06$ & 2 & 10 \\
Korea (81-09) & $93-94,98-99$ & 2 & 4 \\
Netherlands (70-09) & $72-73,81-83,93,04-05$ & 4 & 8 \\
New Zealand (86-09) & $87,89-93$ & 2 & 6 \\
Norway (86-09) & $94-96,99-00,04-06$ & 3 & 8 \\
Portugal (88-09) & $92,94-95,02-04,06-07$ & 4 & 6 \\
Spain (85-09) & $86-87,92-94,09$ & 3 & 13 \\
Sweden (70-09) & $81-87,94-97,04-05$ & 3 & 15 \\
United Kingdom (70-09) & $76-77,79-84,96-00,05-06$ & 4 & 199 \\
United States (70-09) & $71-72,76-77,80-82,91,96-98,05-06$ & 6 & 66 \\
20 countries & & & 6
\end{tabular}

Note: As fiscal consolidation is identified based on the changes in the CAPB from the previous year, the period for the episodes is shorter by one year than the sample period.

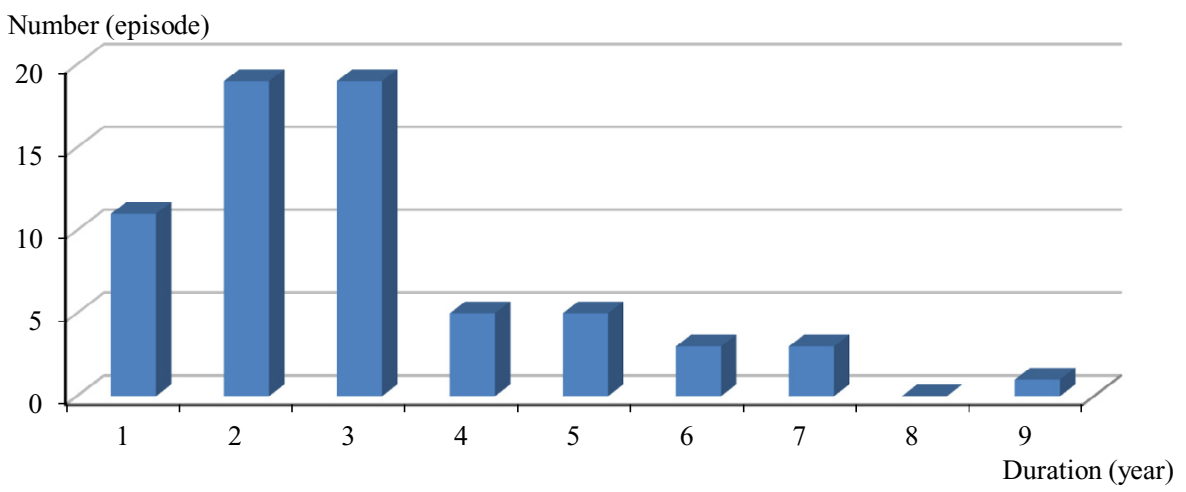

Fig. 1. Distribution of fiscal adjustment episodes by the duration.

As Fig. 1 shows, most episodes are of short duration. Of the 66 episodes, 11 last for one year, while 19 episodes take two or three consecutive years. The longest episode is 9 years: Japan from 1979 to 1987. Fig. 2 shows that the episodes of fiscal adjustment appear most frequently during the 1980 s and 1990s. In particular, we can observe instances of concentrated fiscal adjustment of relatively short duration in the EU countries. This is likely to be related to the Maastricht treaty in 1992 which set criteria for euro area membership (Guichard et al., 2007). ${ }^{18}$

\footnotetext{
${ }^{18}$ The Maastricht criteria imposed limits on inflation, public debt and the public deficit, exchange rate stability and the convergence of interest rates. In particular, the ratio of government deficit and the ratio of gross government debt to GDP were not to exceed $3 \%$ and $60 \%$ of GDP, respectively, at the end of a fiscal year.
} 


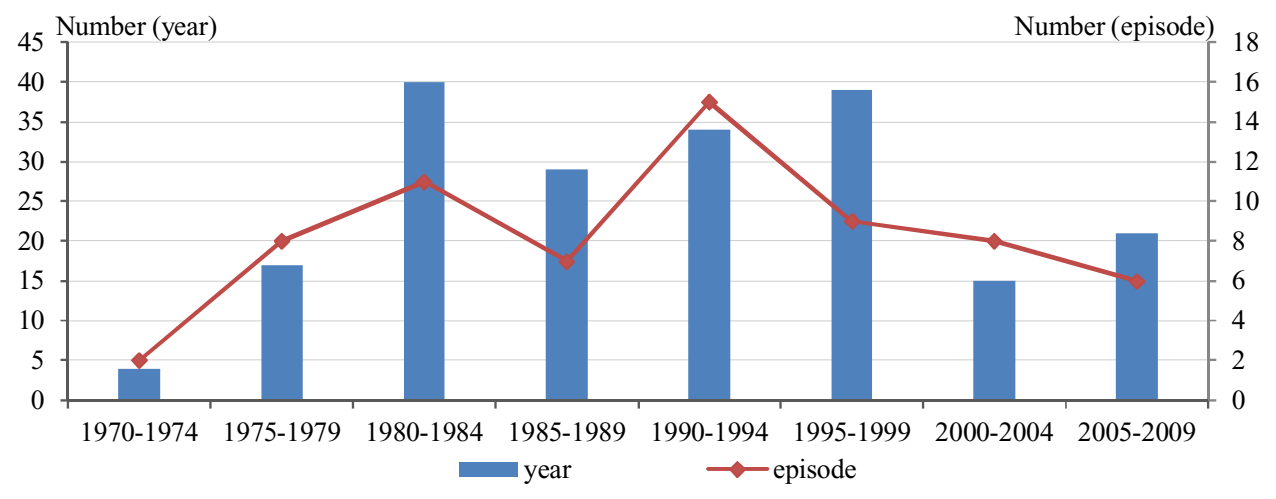

Fig. 2. Distribution of fiscal adjustment episodes by the period.

\subsection{Determinants of fiscal adjustment}

To assess to what extent the incidence of fiscal adjustment depends on contemporaneous or past growth as well as other macroeconomic or fiscal factors, in this subsection, we analyze the determinants of the decision on undertaking fiscal adjustment. To this effect, we estimate a panel logit model where the dependent variable is equal to one during periods of fiscal adjustment and zero otherwise. Although the multi-year fiscal adjustments can be regarded as a single episode, the fiscal authority decides not only on initiating fiscal adjustment, but also on its continuation in the subsequent years. Therefore, the dependent variable takes value of one for each year during an episode of fiscal

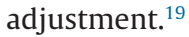

Initial conditions such as the economic and policy environments can influence the decision on fiscal adjustment. Therefore, the explanatory variables are classified under three categories: macroeconomic, fiscal and political.

The resulting marginal effects are reported in Table $3 .^{20}$ The first column contains all variables, while the subsequent columns omit first the fiscal variables and then also the macroeconomic ones (except contemporaneous or lagged growth). ${ }^{21}$ The result of this exercise is that current growth is never significant unless there are no further fiscal or other macroeconomic variables left in the regression, in which case current growth becomes negative and significant (column 9). Lagged output gap, when included in the regressions, is significant and negatively affects the probability of fiscal adjustment. When lagged output gap is omitted, lagged output growth becomes significantly negative instead. As for the coefficient of current output growth being significant in column (9), it is not clear whether this indicates endogeneity or omitted-variable bias, given that it only appears when no other macroeconomic or fiscal variables are present in the regression. Note also that none of the political variables in column (9) are significant either, which suggests that the current output growth term in effect captures only the impact of fiscal and other macroeconomic variables.

For the sake of comparison, we replicate also the analyses of Alesina and Ardagna $(2010,2012)$ and Guajardo et al. (2014) with our data: these results are not reported but are available upon request.

\footnotetext{
${ }^{19}$ For robustness, we also estimated similar regressions with only the first year of each episode coded as financial adjustment, in line with Guichard et al. (2007). The results, available upon request, are broadly in line with those presented here.

${ }^{20}$ As an alternative, we used also the probit model. However, the choice of model has no impact on the results. According to Afonso et al. (2006), logit model is to be preferred because of its statistical advantages in dealing with binary outcomes. Table 3 reports results obtained when considering each year of fiscal adjustment. Alternative results with only the first year of each episode are very similar and are available upon request.

${ }^{21}$ We are grateful to an anonymous referee for suggesting this.
} 
Table 3

Probability of fiscal adjustment.

\begin{tabular}{|c|c|c|c|c|c|c|c|c|c|}
\hline \multirow{2}{*}{$\frac{\text { Variable (dummy) }}{\text { Marginal effects }}$} & \multicolumn{9}{|c|}{ Each year of episodes } \\
\hline & (1) & $(2)$ & (3) & $(4)$ & $(5)$ & (6) & (7) & $(8)$ & (9) \\
\hline GDP growth $(\mathrm{T})$ & $-0.003(0.012)$ & $-0.014(0.012)$ & $0.013(0.009)$ & $-0.012(0.008)$ & - & $-0.016(0.011)$ & $0.011(0.009)$ & & $-0.069^{* *}(0.034)$ \\
\hline GDP growth (T-1) & $-0.017(0.015)$ & $-0.013(0.015)$ & $-0.0060^{* * * *}(0.011)$ & - & $-0.053^{* * *}(0.009)$ & $-0.013(0.014)$ & $-0.060^{* * *}(0.010)$ & $-0.054^{* * *}(0.009)$ & \\
\hline GDP gap (T-1) & $-0.038^{* *}(0.015)$ & $-0.066^{* * *}(0.014)$ & - & - & - & $-0.068^{* * *}(0.014)$ & & & \\
\hline Inflation (T-1) & $0.002 *(0.001)$ & $0.002(0.001)$ & $0.002 *(0.001)$ & $0.002^{* * * *}(0.001)$ & $0.002^{*}(0.001)$ & & & & \\
\hline $\begin{array}{l}\text { Long-term interest } \\
\text { rate }(\mathrm{T}-1)\end{array}$ & $0.048^{* * *}(0.010)$ & $0.045^{* * *}(0.009)$ & $0.043^{* * *}(0.007)$ & $0.046^{* * * *}(0.007)$ & $0.042^{* * *}(0.007)$ & & & & \\
\hline Primary balance (T-1) & $-0.022^{* * *}(0.008)$ & - & - & - & - & & & & \\
\hline Gross debt (T-1) & $0.002^{*}(0.001)$ & - & - & - & - & & & & \\
\hline Election $(\mathrm{T})$ & $-0.038(0.043)$ & $-0.037(0.042)$ & $-0.045(0.040)$ & $-0.019(0.040)$ & $-0.039(0.040)$ & $-0.039(0.041)$ & $-0.046(0.039)$ & $-0.042(0.039)$ & $-0.075(0.185)$ \\
\hline System (Federal) & $0.108 *(0.067)$ & $0.109^{*}(0.063)$ & $0.089^{* *}(0.041)$ & $0.093^{* *}(0.040)$ & $0.088^{* *}(0.041)$ & $0.060(0.052)$ & $0.052(0.039)$ & $0.052(0.039)$ & $0.239(0.175)$ \\
\hline System (Presidential) & $-0.026(0.075)$ & $-0.052(0.067)$ & $-0.016(0.049)$ & $-0.037(0.046)$ & $-0.012(0.049)$ & $-0.023(0.061)$ & $0.002(0.049)$ & $0.006(0.049)$ & $-0.057(0.221)$ \\
\hline Observations & 584 & 608 & 644 & 645 & 644 & 608 & 645 & 645 & 665 \\
\hline No. countries & 20 & & & & & & & & \\
\hline Period & $1970-2009$ & & & & & & & & \\
\hline
\end{tabular}

Note: Marginal effects; standard errors in parentheses and ${ }^{* * *} \mathrm{p}<0.01,{ }^{* *} \mathrm{p}<0.05,{ }^{*} \mathrm{p}<0.10$. 
When we do so, the current growth rate is significant and positive when using the fiscal adjustment episodes identified by Alesina and Ardagna (2010, 2012), and insignificant when using the fiscal adjustment episodes of Guajardo et al. (2014). In other words, fiscal adjustments identified with the standard CAPB-based method are more likely to occur when the growth performance is good. Our results are thus more similar to those obtained with the narrative approach. Hence, the episodes identified with our definition are less at risk of being endogenous than those of Alesina and Ardagna $(2010,2012)$. However, since lagged output gap or lagged growth do appear significant, the episodes identified with our definition may demonstrate less evidence for exogeneity than the narrative episodes of Guajardo et al. (2014). ${ }^{22}$

We turn now to the impact of our complete set of variables on the probability of fiscal adjustment, as portrayed in column (1) of Table 3. The inflation rate has a positive effect on the decision on fiscal adjustment, but only at the $10 \%$ significance level. The long-term interest rate plays a significant role in prompting fiscal adjustment at the $1 \%$ significance level: high long-term interest rate imposes greater burden on government debt, so that it is likely to encourage fiscal adjustment. As for the fiscal variables, the primary balance of the previous year plays a significant role. A rise in the initial primary balance by $1 \%$ of GDP decreases the likelihood of fiscal adjustment by $2.2 \%$. In contrast, the initial debt-to-GDP ratio is only weakly associated with fiscal adjustment: it is significant only at the $10 \%$ significance level and the size of the effect is very small. Finally, most political variables turn out insignificant. Specifically, there is no evidence supporting the 'political budget cycle' story, whereby the incumbent adopts expansionary fiscal policy in an election year to stimulate the economy so as to increase the chances of re-election. Instead, we find that the probability of adopting fiscal adjustment does not decrease significantly in the year of general election. This may be because our data are composed of only OECD countries with a higher level of development, democracy and greater transparency. ${ }^{23}$ Finally, federal nations are more likely to undertake fiscal adjustment.

\section{Specification and results}

In this section, we examine the effects of fiscal adjustment on the economic activity in the short term, especially focusing on the existence of expansionary fiscal adjustment and its transmission. We estimate the following fixed-effects panel model:

$$
\Delta \mathrm{Y}_{i, t}=\alpha_{0}+\alpha_{1} \Delta \mathrm{Y}_{i, t-1}+\beta_{0} \Delta \mathrm{FA}_{i, t}+\beta_{1} \Delta \mathrm{FA}_{i, t-1}+\mu_{i}+\lambda_{t}+v_{i, t}
$$

where $Y_{i, t}$ represents the logarithm of real economic activity (GDP, private consumption, private investment, wage, interest, etc.) for country $i=1,2,3, \ldots . \mathrm{N}$ in year $t=1,2, \ldots . \mathrm{T}$. Economic variables are in logs except for the unemployment and interest rates. $\triangle F A$ denotes the changes in the CAPB in percent of GDP in periods of fiscal adjustment and zero otherwise. The term $\mu_{i}$ indicates countryfixed effects, $\lambda_{t}$ denotes year-fixed effects and $v_{i}$ is a reduced form innovation. For lag selection, we start with several lags of the economic activity variables and changes in the CAPB and iteratively reduce the lag length when the longest lag turned out to be insignificant. As a result, we select one lag for $\Delta \mathrm{Y}$ and $\Delta \mathrm{FA}$ each. ${ }^{24}$

With respect to the estimation, we follow the same methodology as Guajardo et al. (2014) and Alesina and Ardagna (2012). First, we estimate equation (6) by ordinary least squares and then compute the estimated cumulative responses of real GDP and its components to a shock of $1 \%$ point change in the CAPB-to-GDP ratio for the first three years in order to measure the response on the level of real eco-

\footnotetext{
22 In the section on robustness, we present results where we control for possible endogeneity of fiscal adjustments.

${ }^{23}$ Political budget cycles are discussed in Shi and Svensson (2006) and Klomp and Hann (2013).

24 Guajardo et al. (2014) and Alesina and Ardagna (2012) select 2 lags for similar specifications. For the robustness checks, we also use 2 lags. The coefficients of second lags of growth and fiscal adjustment are small and insignificant so that the results of impulse-responses are not affected.
} 
nomic activity variables in the log terms. ${ }^{25}$ We calculate the standard errors of the impulse response using the delta method. ${ }^{26}$

Table 4 presents the estimated coefficients of the changes in the CAPB on the economic activity variables in our baseline model. The first column reports that growth responds negatively to contemporaneous changes in the CAPB, but positively to its lagged change. As the negative effect of contemporaneous fiscal adjustment is much larger than the lagged positive effect, ${ }^{27}$ the fiscal adjustment is found to have contractionary effect in the short term. In other words, non-Keynesian effects, or expansionary fiscal adjustments, do not occur. In that, our results are very similar to those of Guajardo et al. (2014) based on the narrative approach. The response of growth is mirrored in those of the individual components of GDP. The effects of current and lagged fiscal adjustment on private consumption and investment are very much in line with those on growth (columns 2 and 3). As for the labor market, the effect on the real wage is negative but insignificant. On the other hand, the effect on unemployment rate is large and positive at the $1 \%$ significance level, both contemporaneously and with a lag. This shows that fiscal adjustment reduces output and raises unemployment in the short term. Columns (6) and (7) show the impacts of fiscal adjustment on interest rates. Interest rates fall when a country's fiscal position improves, which is consistent with the finding of Ardagna (2009).

Table 5 shows the corresponding impulse-responses resulting from an improvement in the CAPB by $1 \%$ of GDP for three years following fiscal adjustment, based on the results in Table 4 . The growth rates are cumulated to obtain the estimated impact of fiscal adjustment on the level of economic activity, following Guajardo et al. (2014) and Alesina and Ardagna (2012). Fiscal adjustment has statistically significant effects on GDP, private consumption and other macroeconomic variables with the peak contractionary effect occurring within 1 or 2 years. In particular, a fiscal adjustment equal to $1 \%$ of GDP reduces real GDP by about $0.3 \%$ in the year of fiscal adjustment. These results are very similar to those of Guajardo et al. (2014), despite the different definition of fiscal adjustments, specification and data. Fig. 3 compares the responses of GDP to a fiscal adjustment shock between our baseline and Guajardo et al.'s (2014) baseline. Although the timing of peak contractionary effects is different, both sets of results report negative effects on GDP sustained for three years and diminishing gradually over time. $^{28}$

In summary, our results suggest that fiscal consolidations have a significant contractionary effect in the short term. In addition, although Guajardo et al. (2014) raise some issues with respect to using the CAPB, our own CAPB-based measure, which takes account of those criticisms, shows results which are very similar to theirs.

\section{Robustness checks}

Next, we present the results of several alternative approaches to test the robustness of our results. First, given that both our definition for computing the CAPB and the criteria for identifying fiscal adjustment have an element of arbitrariness in them, we consider alternative definitions. Second, as discretionary fiscal policy cannot be entirely exogenous to the state of the economy, we address the issue of endogeneity in our model. Third, we investigate the role played by the composition of fiscal adjustment in terms of tax increases and spending cuts. Fourth, we check the robustness of our findings to the inclusion of other variables to control for monetary and exchange rate policies, as well

\footnotetext{
${ }^{25}$ In the fixed-effects dynamic panel model, when lagged values of the dependent variable are included as regressors, ordinary least squares estimates can be inconsistent due to the correlation of the lagged dependant variable with the error term. Therefore, in this case, Arellano-Bond estimator (GMM estimator) is usually used. However, according to Roodman (2006), this estimator is designed for "small T, large N" panels, and in case of sufficiently large T panel, the bias is likely to be negligible. In our dataset, $\mathrm{T}$ is over 30 years and $\mathrm{N}$ is 20 countries; so we do not need to use this estimator.

${ }^{26}$ In statistics, the delta method is a methodology to derive an approximate probability distribution for a function of an asymptotically normal statistical estimator (see Oehlert, 2008). We use the syntax for 'Nonlinear combination of estimators' using the delta method in the Stata program.

${ }^{27}$ An F-test for the two coefficients being equal in absolute value is rejected with $F(1,585)=19.17$ and $p$-value of 0.0000 .

${ }^{28}$ Implementing only one of the two changes; accounting for the asset prices or country-specific thresholds separately, yields results very similar those reported in Tables 4 and 5, suggesting that the two changes are, to some extent, substitutes for each other. These results are available upon request.
} 
Table 4

Effect of fiscal adjustment on economic activity.

\begin{tabular}{|c|c|c|c|c|c|c|c|}
\hline \multirow[t]{2}{*}{ Dependent variable } & $\begin{array}{l}\text { GDP } \\
\text { growth (\%) }\end{array}$ & $\begin{array}{l}\text { Private } \\
\text { consumption (\%) }\end{array}$ & $\begin{array}{l}\text { Private } \\
\text { investment (\%) }\end{array}$ & $\begin{array}{l}\text { Hourly } \\
\text { wage (\%) }\end{array}$ & $\begin{array}{l}\text { Unemployment } \\
\text { rate (\%) }\end{array}$ & $\begin{array}{l}\text { Short interest } \\
\text { rate (\%) }\end{array}$ & $\begin{array}{l}\text { Long interest } \\
\text { rate (\%) }\end{array}$ \\
\hline & $(1)$ & $(2)$ & (3) & (4) & (5) & (6) & (7) \\
\hline Lagged dependent variable (T-1) & $0.354^{* * * *}(0.040)$ & $0.357^{* * *}(0.040)$ & $0.378^{* * *}(0.040)$ & $0.519^{* * * *}(0.036)$ & $0.874^{* * *}(0.017)$ & $0.719^{* * * *}(0.029)$ & $0.849^{* * * *}(0.020)$ \\
\hline$\Delta \mathrm{FA}(\mathrm{T})$ & $-0.289^{* * *}(0.066)$ & $-0.305^{* * *}(0.075)$ & $-0.814^{* * *}(0.197)$ & $-0.059(0.081)$ & $0.332^{* * *}(0.031)$ & $-0.102 *(0.056)$ & $0.004(0.029)$ \\
\hline$\Delta \mathrm{FA}(\mathrm{T}-1)$ & $0.153^{* *}(0.065)$ & $0.154^{* *}(0.073)$ & $0.471^{* *}(0.193)$ & $0.080(0.080)$ & $0.083^{* * *}(0.032)$ & $-0.134^{* *}(0.053)$ & $-0.074^{* * *}(0.028)$ \\
\hline Constant & $3.602^{* * *}(0.475)$ & $0.811(0.543)$ & $-4.774^{* * *}(1.425)$ & $2.088^{* * *}(0.641)$ & $1.171^{* * *}(0.240)$ & $4.836^{* * *}(0.446)$ & $1.962^{* * *}(0.256)$ \\
\hline Observations & 645 & 645 & 645 & 602 & 645 & 612 & 644 \\
\hline R-squared & 0.564 & 0.420 & 0.494 & 0.781 & 0.904 & 0.894 & 0.955 \\
\hline No. countries & 20 & 20 & 20 & 20 & 20 & 20 & 20 \\
\hline
\end{tabular}

Note: The data on hourly wage are obtained from the OECE. StatExtracts/Labour/Earning dataset-manufacture (index 2005=100). The estimated results are the coefficient estimates. Standard errors in parentheses, ${ }^{* * *} \mathrm{p}<0.01,{ }^{* *} \mathrm{p}<0.05,{ }^{*} \mathrm{p}<0.1$. 
Table 5

Macroeconomic responses to fiscal adjustment shock equal to $1 \%$ of GDP.

\begin{tabular}{lllllllc}
\hline $\begin{array}{l}\text { Dependent } \\
\text { variables }\end{array}$ & GDP & $\begin{array}{l}\text { Private } \\
\text { consumption }\end{array}$ & $\begin{array}{l}\text { Private } \\
\text { investment }\end{array}$ & $\begin{array}{l}\text { Hourly } \\
\text { wage }\end{array}$ & $\begin{array}{l}\text { Unemployment } \\
\text { rate (\%) }\end{array}$ & $\begin{array}{l}\text { Short } \\
\text { interest } \\
\text { rate }(\%)\end{array}$ & $\begin{array}{l}\text { Long } \\
\text { interest } \\
\text { rate }(\%)\end{array}$ \\
\hline $\mathrm{T}$ & $-0.289^{* * *}$ & $-0.305^{* * *}$ & $-0.814^{* * *}$ & -0.059 & $0.332^{* * *}$ & $-0.102^{*}$ & 0.004 \\
& $(0.066)$ & $(0.075)$ & $(0.197)$ & $(0.081)$ & $(0.031)$ & $(0.056)$ & $(0.029)$ \\
$\mathrm{T}+1$ & $-0.238^{* *}$ & $-0.260^{* *}$ & $-0.650^{* *}$ & $-0.010^{*}$ & $0.373^{* * *}$ & $-0.208^{* * *}$ & $-0.071^{* *}$ \\
& $(0.096)$ & $(0.110)$ & $(0.293)$ & $(0.129)$ & $(0.036)$ & $(0.060)$ & $(0.033)$ \\
$\mathrm{T}+2$ & $-0.220^{*}$ & $-0.244^{*}$ & $-0.588^{*}$ & $0.016^{*}$ & $0.325^{* * *}$ & $-0.149^{* * *}$ & $-0.060^{* *}$ \\
& $(0.114)$ & $(0.130)$ & $(0.350)$ & $(0.164)$ & $(0.031)$ & $(0.045)$ & $(0.029)$ \\
\hline
\end{tabular}

Note: The table shows the point estimated responses on the level of GDP and its components in terms of logs and on the interest rate and unemployment in terms of the percentage. Standard errors in parentheses, ${ }^{* * *} \mathrm{p}<0.01,{ }^{* *} \mathrm{p}<0.05,{ }^{*} \mathrm{p}<0.1$.

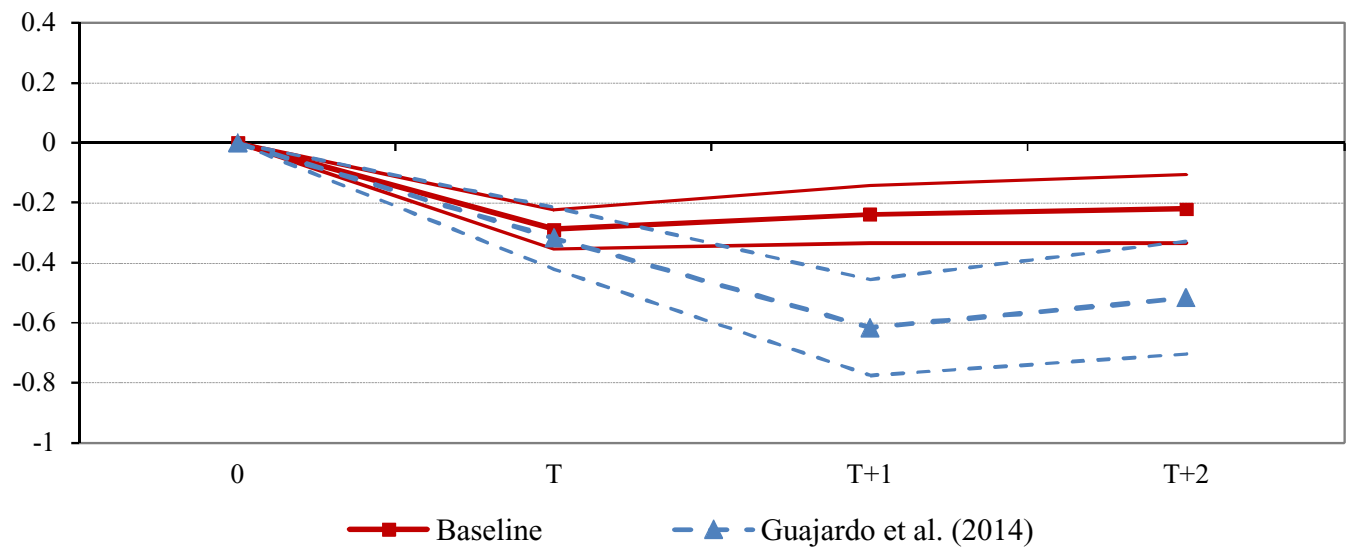

Fig. 3. Comparison of responses of GDP to a fiscal adjustment shock.

Note: Guajardo et al. (2014) select 2 lag orders, but our specification uses one lag. T denotes the year of fiscal adjustment. The figure reports point estimates and one standard error bands.

as the institutional and political environment. Finally, we also investigate the sensitivity of our results across country groups.

\subsection{Alternative definitions of fiscal adjustment}

Our CAPB measure and the resulting definition of fiscal adjustment are different from the extant literature using the CAPB approach. In particular, the thresholds applied are arbitrary to some extent. Therefore, we perform additional analysis to assess whether changes in the threshold affect critically the results. First, we use alternative thresholds with respect to the standard deviation of CAPB changes. Second, since the average and standard deviation of the changes in the CAPB for each country can be affected by outliers, we drop the largest positive and negative values representing the changes in the CAPB. Third, we replace the share price index with the house price index..$^{29}$ Fourth, we use the CAPB reported by the OECD instead of computing it ourselves. ${ }^{30}$ Finally, it may be argued that the assump-

\footnotetext{
${ }^{29}$ The house price index data (1975-2009) are taken from the International House Price Database of the Federal Reserve Bank of Dallas.

${ }^{30}$ We use the CAPB data (underlying primary fiscal balance) from the OECD Economic Outlook No.88 which are said to eliminate the impact of one-off transactions from the cyclically-adjusted financial balances. These data have been used in much of the literature such as McDermott and Wescott (1996), Kamps (2006), Guichard et al. (2007).
} 
tion of unemployment proxying business-cycle fluctuations is a strong one. Therefore, we replace it with the output gap. ${ }^{31}$

Tables 6 and 7 show that the baseline results (column 1) are robust to a series of alternative criteria for the definition of fiscal adjustment and also to alternative CAPB definitions. In particular, in column (2), we apply a lower threshold for identifying fiscal adjustment while columns (3) and (4) apply stricter thresholds. In each case, fiscal adjustment has a similarly sized negative effect on growth. Dropping the outliers (column 5) similarly does not lead to substantially different results. The results obtained when the house price index is used instead of stock prices (column 6) are not much different from the baseline either.

The results with the OECD CAPB data show an insignificant negative effect (column 7). This difference is likely to be due to the different assumptions and methodology. As Alesina and Perotti (1995) and Alesina and Ardagna (1998) point out, the OECD method depends on measures of potential output, which are regarded as highly arbitrary, and a set of elasticities of taxes and expenditures. ${ }^{32}$ In addition, although the OECD purports to eliminate one-off transactions from the primary fiscal balance, this adjustment may not be perfect because one-off transactions in its methodology are derived from the deviation from trend in net capital transfers, not from individual records. For instance, the Netherlands in 1996 is one of the cases that historical records indicate as having a one-off transaction in the previous year, but is included in the fiscal adjustment episodes according to the OECD CAPB version. ${ }^{33}$ Given the methodological differences, we feel that the fact that we obtain different results with the OECD CAPB figures actually strengthens our case.

Next, we replace unemployment with output gap as a proxy for business cycle fluctuations. In column (8), we use the output gap instead of unemployment both for government revenue and spending, while in column (9), we use unemployment for spending and output gap for revenue. The results are again broadly in line with the baseline. ${ }^{34}$

Table 7 compares the impulse-responses based on the estimation results. The stricter the thresholds, the more negative the effect of fiscal adjustment on GDP. When dropping outliers, the negative effects are smaller than in the baseline, but are still significant. While the response in case of OECD CAPB is not significant, most estimates indicate a decline of GDP similar to the baseline result for three years. Using output gap instead of unemployment as a proxy for business-cycle fluctuations results in a stronger (more negative) output response, especially when we use the output gap for both government revenue and spending.

Finally, in the preceding results, we used a single time trend for the whole period, 1970-2009. Alesina and Ardagna (1998), in contrast, use two time trends: 1960-1975 and 1976-1994. While we do not have enough data to estimate a separate trend for the 1970s (to account for the oil-price shocks that took place during that decade, which was the motivation for the two time trends employed by Alesina and Ardagna, 1998), we re-estimated our results with two time trends based on the adoption of the Maastricht Treaty in 1992: 1970-91 and 1992-09. The impact of this change is minimal and the results are very similar to those obtained with a single time trend (not reported but available upon request).

\subsection{Endogeneity of fiscal adjustment}

Although we tried various approaches for identifying the episodes of discretionary fiscal adjustment, it is very hard to identify them unambiguously. In particular, the cyclical correction is not fully free from potential endogeneity. In this subsection, therefore, we check the robustness of our results by relaxing the exogeneity assumption. First, we check the assumption of the baseline model that the

\footnotetext{
${ }^{31}$ The output gap is used also by Ardanaz et al. (2015). We are grateful to an anonymous referee for suggesting this modification.

${ }^{32}$ See Ardanaz et al. (2015) for an extended discussion about the impact of uncertainty about such elasticities and other assumptions on estimates of CAPB.

33 The list of fiscal adjustment episodes identified based on the OECD CAPB is available upon request.

${ }^{34}$ We are grateful to an anonymous referee for suggesting this.
} 
Table 6

\begin{tabular}{|c|c|c|c|c|c|c|c|c|c|}
\hline \multirow[t]{3}{*}{ Alternatives } & \multicolumn{5}{|c|}{ Criteria for the definition } & \multicolumn{4}{|l|}{ CAPB version } \\
\hline & Baseline & Threshold 1 & Threshold 2 & Threshold 3 & $\begin{array}{l}\text { Dropping } \\
\text { outliers }\end{array}$ & $\begin{array}{l}\text { House price } \\
\text { index }\end{array}$ & OECD CAPB & Output gap & $\begin{array}{l}\text { UE (G), Output } \\
\text { gap (R) }\end{array}$ \\
\hline & $(1)$ & $(2)$ & (3) & $(4)$ & $(5)$ & (6) & (7) & $(8)$ & (9) \\
\hline Single year $(\eta)$ & 1 & $3 / 4$ & $3 / 2$ & 2 & 1 & 1 & 1 & 1 & 1 \\
\hline Multiple years $(\lambda)$ & $1 / 3,4 / 3,2$ & $1 / 4,1,3 / 2$ & $1 / 2,2,3$ & $3 / 4,2,3$ & $1 / 3,4 / 3,2$ & $1 / 3,4 / 3,2$ & $1 / 3,4 / 3,2$ & $1 / 3,4 / 3,2$ & $1 / 3,4 / 3,2$ \\
\hline GDP growth (T-1) & $0.354^{* * * *}(0.040)$ & $0.357^{* * * *}(0.040)$ & $0.355^{* * *}(0.040)$ & $0.352^{* * * *}(0.040)$ & $0.357^{* * * *}(0.040)$ & $0.391^{* * * *}(0.039)$ & $0.418^{* * * *}(0.043)$ & $0.409^{* * * *}(0.040)$ & $0.365^{* * * *}(0.041)$ \\
\hline$\Delta \mathrm{FA}(\mathrm{T})$ & $-0.289^{* * * *}(0.066)$ & $-0.274^{* * *}(0.065)$ & $-0.320^{* * *}(0.070)$ & $-0.302^{* * *}(0.068)$ & $-0.264^{* * * *}(0.065)$ & $-0.214^{* * *}(0.057)$ & $-0.071(0.100)$ & $-0.524^{* * *}(0.071)$ & $-0.322^{* * *}(0.077)$ \\
\hline$\Delta \mathrm{FA}(\mathrm{T}-1)$ & $0.153^{* *}(0.065)$ & $0.146^{* *}(0.064)$ & $0.191^{* * *}(0.069)$ & $0.149^{* *}(0.067)$ & $0.152^{* *}(0.064)$ & $0.078(0.056)$ & $-0.034(0.097)$ & $0.195^{* * *}(0.072)$ & $0.133^{*}(0.075)$ \\
\hline Constant & $3.602^{* * *}(0.475)$ & $3.665^{* * *}(0.479)$ & $3.621^{* * *}(0.474)$ & $3.595^{* * * *}(0.474)$ & $3.618^{* * *}(0.478)$ & $2.544^{* * * *}(0.437)$ & $2.075^{* * * *}(0.420)$ & $4.098^{* * *}(0.511)$ & $4.206^{* * * *}(0.530)$ \\
\hline Observations & 645 & 645 & 645 & 645 & 645 & 620 & 518 & 603 & 603 \\
\hline No. FA year & 199 & 219 & 157 & 100 & 204 & 240 & 167 & 174 & 168 \\
\hline R-squared & 0.564 & 0.563 & 0.566 & 0.564 & 0.562 & 0.560 & 0.576 & 0.611 & 0.583 \\
\hline No. countries & 20 & 20 & 20 & 20 & 20 & 20 & 19 & 20 & 20 \\
\hline Period & $70-09$ & $70-09$ & $70-09$ & $70-09$ & 70-09 & $70-09$ & 80-09 & 70-09 & 70-09 \\
\hline
\end{tabular}

Note: The new threshold means the change of multiples of the standard deviation for identifying fiscal adjustment. $\eta$ and $\lambda$ are the multiples for a given year and multi-years respectively. Column 2 has weaker threshold than the baseline. However, Column 3 and 4 have stronger threshold than the baseline. Column (7) uses the underlying government primary balance (a percentage of potential GDP) data for 1980-2009 from OECD Outlook No.88. 19 OECD countries excluding Germany due to the limited period for the CAPB are included. Column (8) uses the output gap instead of unemployment both for government spending and revenues. Column (9) uses unemployment for government spending and output gap for revenues. Standard errors in parentheses, ${ }^{* * *} \mathrm{p}<0.01,{ }^{* *} \mathrm{p}<0.05,{ }^{*} \mathrm{p}<0.1$ 
Table 7

Comparison of response of GDP to alternative measures.

\begin{tabular}{|c|c|c|c|c|c|c|c|c|c|}
\hline & \multirow[t]{2}{*}{ Baseline } & \multicolumn{4}{|c|}{ Criteria for the definition } & \multicolumn{4}{|c|}{ CAPB version } \\
\hline & & $\begin{array}{l}\text { Threshold } \\
1\end{array}$ & $\begin{array}{l}\text { Threshold } \\
2\end{array}$ & $\begin{array}{l}\text { Threshold } \\
3\end{array}$ & $\begin{array}{l}\text { Dropping } \\
\text { outliers }\end{array}$ & $\begin{array}{l}\text { House } \\
\text { price } \\
\text { index }\end{array}$ & OECD CAPB & Output gap & $\begin{array}{l}\text { UE (G), } \\
\text { Output } \\
\text { gap (R) }\end{array}$ \\
\hline $\mathrm{T}$ & $\begin{array}{l}-0.289^{* * * *} \\
(0.066)\end{array}$ & $\begin{array}{l}-0.274^{* * * *} \\
(0.065)\end{array}$ & $\begin{array}{l}-0.320^{\text {**** }} \\
(0.070)\end{array}$ & $\begin{array}{l}-0.302^{\text {***** }} \\
(0.068)\end{array}$ & $\begin{array}{l}-0.264^{* * *} \\
(0.065)\end{array}$ & $\begin{array}{l}-0.214^{* * * *} \\
(0.057)\end{array}$ & $\begin{array}{c}-0.071 \\
(0.100)\end{array}$ & $\begin{array}{l}-0.524^{* * * *} \\
(0.071)\end{array}$ & $\begin{array}{l}-0.312^{\text {***** }} \\
(0.077)\end{array}$ \\
\hline $\mathrm{T}+1$ & $\begin{array}{l}-0.238^{* *} \\
(0.096)\end{array}$ & $\begin{array}{l}-0.226^{* *} \\
(0.097)\end{array}$ & $\begin{array}{l}-0.243^{* *} \\
(0.099)\end{array}$ & $\begin{array}{l}-0.259^{* * * *} \\
(0.098)\end{array}$ & $\begin{array}{l}-0.206^{* *} \\
(0.097)\end{array}$ & $\begin{array}{l}-0.220^{* *} \\
(0.086)\end{array}$ & $\begin{array}{l}-0.136 \\
(0.158)\end{array}$ & $\begin{array}{l}-0.544^{* * * *} \\
(0.118)\end{array}$ & $\begin{array}{l}-0.306^{* * * *} \\
(0.116)\end{array}$ \\
\hline $\mathrm{T}+2$ & $\begin{array}{l}-0.220^{*} \\
(0.114)\end{array}$ & $\begin{array}{c}-0.209^{*} \\
(0.115)\end{array}$ & $\begin{array}{c}-0.216^{*} \\
(0.117)\end{array}$ & $\begin{array}{l}-0.244^{* * *} \\
(0.115)\end{array}$ & $\begin{array}{l}-0.185 \\
(0.114)\end{array}$ & $\begin{array}{l}-0.222^{* *} \\
(0.104)\end{array}$ & $\begin{array}{l}-0.163 \\
(0.192)\end{array}$ & $\begin{array}{l}-0.552^{* * *} \\
(0.143)\end{array}$ & $\begin{array}{l}-0.301^{* * *} \\
(0.138)\end{array}$ \\
\hline
\end{tabular}

Note: The table shows the point estimated responses of GDP to a shock of fiscal adjustment equal to $1 \%$ of GDP. T denotes the year of fiscal adjustment. Standard errors in parentheses, ${ }^{* * *} \mathrm{p}<0.01,{ }^{* *} \mathrm{p}<0.05,{ }^{*} \mathrm{p}<0.1$.

changes in the CAPB during the periods of fiscal adjustment are exogenous and uncorrelated with those in other 'normal' periods. Following Alesina and Ardagna (2012), we investigate whether the estimated coefficients of fiscal adjustment change when the changes in the CAPB in normal periods (i.e. periods without fiscal adjustment) are included as an additional term $\left(\triangle \mathrm{NFA}_{i, t-j}\right)$.

$$
\Delta \mathrm{Y}_{i, t}=\alpha_{0}+\alpha_{1} \Delta \mathrm{Y}_{i, t-1}+\sum_{\mathrm{j}=0}^{1} \beta_{\mathrm{j}} \Delta \mathrm{FA}_{i, t-j}+\sum_{j=0}^{1} \gamma_{\mathrm{j}} \Delta \mathrm{NFA}_{i, t-j}+\mu_{i}+\lambda_{t}+v_{i, t}
$$

Second, we estimate the effects of fiscal adjustment on growth under the assumption that the decisions on fiscal adjustment and its size are endogenous to the state of the economy. This means that since the cyclical correction cannot remove the automatic changes of fiscal variables in response to output entirely, some of the discretionary fiscal changes are related to the fluctuations of contemporaneous output. As a result, the fiscal adjustment variable $\left(\Delta \mathrm{FA}_{i, t-j}\right)$ can be correlated with the contemporaneous error term $\left(v_{i, t}\right): E\left(v_{i, t} \mid \Delta \mathrm{FA}_{i, t-j}\right) \neq 0$. Therefore, similar to Hernández de Cos and Moral-Benito (2011), who also take the endogeneity into consideration, we estimate the effect of fiscal adjustment via two-stage least squares (2SLS). ${ }^{35}$ We select the fiscal adjustments based on the narrative approach by Guajardo et al. (2014) as the first instrument because it is more likely to be exogenous given that the identification is based on historical records. In addition, we use lagged long-term interest rate which we showed to be strongly correlated with fiscal adjustment in the logit analysis of section 4 and is predetermined but not strictly exogenous to the contemporaneous error term.

The results are reported in Tables 8 and 9. First, when including the changes in the CAPB during normal periods, the magnitude of the coefficient of fiscal adjustment (Table 8) and the response of GDP to a fiscal adjustment shock (Table 9) are somewhat larger than in the baseline model, but otherwise the results change little: we still observe contractionary effects which are very similar to the baseline. Importantly, the changes in the CAPB that are not associated with fiscal adjustment (NFA) do not have any effect on growth, as expected. This means that the assumption of fiscal adjustment being different from other changes in the CAPB in normal periods is reasonable.

Next, when using instrumental variables to control for potential endogeneity of fiscal adjustment, the effect on growth is stronger (more negative) than in the baseline. This pattern appears regardless of the instruments used. Table 10 reports the results of first stage regressions, confirming the validity of the instruments considered. Both instruments have strong relation with fiscal adjustment. However, the test results indicate that the narrative fiscal adjustment of Guajardo et al. (2014) has more ex-

\footnotetext{
${ }^{35}$ Although some authors such as Biorn and Klette (1999) advocate the use of the GMM estimator to tackle endogeneity, we use 2SLS rather than GMM estimator because our dataset has a small number of countries (20) and a large number of time periods (30). For this analysis, we use 'xtivreg2' stata module by Schaffer (2010).
} 
Table 8

Effects of fiscal adjustment on growth: controlling for endogeneity.

\begin{tabular}{|c|c|c|c|c|c|}
\hline \multirow{2}{*}{$\frac{\text { Estimated method }}{\text { Added variable/IV }}$} & \multirow{2}{*}{$\frac{\text { OLS }}{\text { Baseline }}$} & \multirow{2}{*}{$\frac{\text { Augmented OLS }}{\text { CAPB }^{\text {NFA }}}$} & \multicolumn{3}{|l|}{ 2SLS } \\
\hline & & & Narrative FA & $\begin{array}{l}\text { One lagged } \\
\text { long-term } \\
\text { interest rate }\end{array}$ & $\begin{array}{l}\text { Narrative FA and } \\
\text { long-term interest } \\
\text { rate }(\mathrm{T}-1)\end{array}$ \\
\hline GDP growth (T-1) & $0.354^{* * *}(0.040)$ & $0.356^{* * *}(0.040)$ & $0.402^{* * *}(0.049)$ & $0.244^{* * *}(0.071)$ & $0.387^{* * *}(0.049)$ \\
\hline$\Delta \mathrm{FA}(\mathrm{T})$ & $-0.289^{* * *}(0.066)$ & $-0.297^{* * *}(0.066)$ & $-0.581^{* * *}(0.186)$ & $-1.259^{* *}(0.512)$ & $-0.698^{* * *}(0.179)$ \\
\hline$\Delta \mathrm{FA}(\mathrm{T}-1)$ & $0.153^{* *}(0.065)$ & $0.147^{* *}(0.065)$ & $0.182^{* *}(0.076)$ & $0.345^{* * *}(0.122)$ & $0.205^{* * *}(0.076)$ \\
\hline$\Delta \mathrm{NFA}(\mathrm{T})$ & - & $0.025(0.052)$ & - & - & \\
\hline$\triangle \mathrm{NFA}(\mathrm{T}-1)$ & - & $0.087(0.053)$ & - & - & \\
\hline Constant & $3.602^{* * *}(0.475)$ & $3.680^{* * *}(0.478)$ & $-4.085^{* * *}(0.349)$ & $-3.524^{* * *}(0.428)$ & $-4.605^{* * *}(0.357)$ \\
\hline Observations & 645 & 645 & 502 & 644 & 502 \\
\hline R-squared & 0.564 & 0.566 & 0.628 & 0.399 & 0.610 \\
\hline No. countries & 20 & 20 & 17 & 20 & 17 \\
\hline
\end{tabular}

Note: NFA means Non-fiscal adjustment as periods without fiscal adjustment. Standard errors in parentheses, ${ }^{* * *} \mathrm{p}<0.01,{ }^{* *} \mathrm{p}<0.05$.

Table 9

Response of GDP to a fiscal adjustment shock of $1 \%$ of GDP.

\begin{tabular}{|c|c|c|c|c|c|}
\hline Estimated method & OLS & Augmented OLS & 2SLS & & \\
\hline $\begin{array}{l}\text { Added } \\
\text { variable/IV }\end{array}$ & Baseline & $\mathrm{CAPB}^{\mathrm{NFA}}$ & Narrative FA & $\begin{array}{l}\text { One lagged } \\
\text { long-term } \\
\text { interest rate }\end{array}$ & $\begin{array}{l}\text { Narrative FA, } \\
\text { long-term interest } \\
\text { rate }(\mathrm{T}-1)\end{array}$ \\
\hline $\mathrm{T}$ & $-0.289 * * *(0.066)$ & $-0.297^{* * *}(0.066)$ & $-0.581^{* * * *}(0.186)$ & $-1.259^{* *}(0.512)$ & $-0.698^{* * *}(0.179)$ \\
\hline $\mathrm{T}+1$ & $-0.238^{* *}(0.096)$ & $-0.256^{* * *}(0.097)$ & $-0.632^{* * *}(0.221)$ & $-1.221^{* *}(0.476)$ & $-0.763^{* * *}(0.209)$ \\
\hline $\mathrm{T}+2$ & $-0.220^{*}(0.114)$ & $-0.241^{* *}(0.115)$ & $-0.652^{* * *}(0.239)$ & $-1.212^{* *}(0.471)$ & $-0.788^{* * *}(0.225)$ \\
\hline
\end{tabular}

Note: The table shows the point estimated responses of GDP to a shock of fiscal adjustment equal to $1 \%$ of GDP. T denotes the year of fiscal adjustment. NFA means Non-fiscal adjustment as periods without fiscal adjustment. The standard errors in parentheses are computed via the delta method, ${ }^{* * *} \mathrm{p}<0.01,{ }^{* *} \mathrm{p}<0.05,{ }^{*} \mathrm{p}<0.1$.

planatory power than the lagged long-term interest rate. When we use both instruments at the same time, the results are also rather similar to those obtained with each instrument alone. In addition, according to the Durbin-Wu-Hausman test for endogeneity of fiscal adjustment, the null hypothesis that the fiscal adjustment can be treated as exogenous is rejected at the $5 \%$ significance level. Therefore, we can conclude that fiscal adjustment identified by the changes in the CAPB is not strictly exogenous to growth. Nevertheless, the results corrected for endogeneity of fiscal adjustment support our baseline finding of contractionary effects.

\subsection{Does composition of fiscal adjustment matter?}

Many studies analyze whether the effects of fiscal adjustment depends on its composition. They generally agree that fiscal adjustments focusing on the spending side are more likely to have expansionary effects on GDP than those on the tax side. Therefore, in this subsection, we investigate what role the composition of fiscal adjustment plays in the response of economic growth. First, we divide the fiscal adjustments episodes into two types: 'spending-based', in which the change in the CAPB is mainly (by at least 50\%) due to spending cuts, and 'tax-based', in which the change in the CAPB is mainly due to revenue increases (Guajardo et al., 2014 and McDermott and Wescott, 1996, apply the same criterion). Next, we implement another categorization of fiscal adjustments, splitting them into three types: 'pure spending-based' ones where the improvement in the CAPB is entirely due to spending cuts, 'pure tax-based' ones which are totally due to revenue increases, and 'mixed' cases that combine the two types of adjustment.

Fig. 4 shows the estimated effects of fiscal adjustment according to its composition. First, although spending-based adjustments do not have a significant expansionary effect, they also do not have 
Table 10

First-stage regression of fiscal adjustment in 2SLS.

\begin{tabular}{|c|c|c|c|}
\hline \multirow{2}{*}{$\begin{array}{l}\text { Dependent variable } \\
\text { Instrument variable }\end{array}$} & \multicolumn{3}{|l|}{$\mathrm{CAPB}^{\mathrm{FA}}$} \\
\hline & Narrative FA & $\begin{array}{l}\text { One lagged } \\
\text { long-term } \\
\text { interest rate }\end{array}$ & $\begin{array}{l}\text { Narrative FA, } \\
\text { Long-term interest } \\
\text { rate(T-1) }\end{array}$ \\
\hline GDP growth (T-1) & $-0.082^{* * * *}(0.027)$ & $-0.103^{* * *}(0.025)$ & $-0.081^{\text {***** }}(0.027)$ \\
\hline$\Delta \mathrm{FA}(\mathrm{T}-1)$ & $0.143^{* * *}(0.042)$ & $0.173^{* * *}(0.040)$ & $0.124^{* * *}(0.042)$ \\
\hline Narrative FA & $0.560^{* * *}(0.065)$ & & $0.556^{* * *}(0.065)$ \\
\hline Long-term interest rate(T-1) & & $0.098^{* * *}(0.027)$ & $0.087^{* * *}(0.027)$ \\
\hline Constant & $0.004(0.210)$ & $-0.270(0.252)$ & $0.381(0.241)$ \\
\hline Observations & 502 & 644 & 502 \\
\hline R-squared & 0.388 & 0.251 & 0.401 \\
\hline No. countries & 17 & 20 & 17 \\
\hline \multicolumn{4}{|c|}{ Summary results for the instrument variable test from the first-stage regressions } \\
\hline F test of excluded instruments (F value $)^{\mathrm{a}}$ & $73.87^{* * *}$ & $12.62^{* * *}$ & $42.40^{* * *}$ \\
\hline Underidentification test (LM value $)^{\mathrm{b}}$ & $68.26^{* * *}$ & $13.20^{* * *}$ & $77.36^{* * *}$ \\
\hline Weak identification test $(\mathrm{F} \text { value })^{\mathrm{c}}$ & $73.87^{* * * *}$ & 13.11 & $42.70^{* * *}$ \\
\hline Endogeneity test of (P value $)^{\mathrm{d}}$ & 0.013 & 0.023 & 0.001 \\
\hline Overidentification test of all IVs (P value) ${ }^{\mathrm{e}}$ & - & - & 0.072 \\
\hline
\end{tabular}

Note: Standard errors in parentheses, ${ }^{* * *} \mathrm{p}<0.01,{ }^{* *} \mathrm{p}<0.05$.

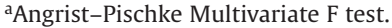

${ }^{b}$ Anderson canon. Correlation (Ho: equation is underidentified).

${ }^{\mathrm{c} C r a g g-D o n a l d ~ W a l d ~ t e s t ~ w i t h ~ S t o c k-Y o g o ~ c r i t i c a l ~ v a l u e s ~(H o: ~ e q u a t i o n ~ i s ~ w e a k l y ~ i d e n t i f i e d) . ~}$

dDurbin-Wu-Hausman Test (Ho: OLS estimator of the same equation would yield consistent estimates).

eSargan Statistic $\left(\mathrm{H}_{0}\right.$ : The instruments are valid).

significantly negative effect on GDP and private consumption except in the year of fiscal adjustment. When compared with tax-based adjustments, spending-based adjustments are less contractionary and can even offset the large negative effects of tax-based adjustment because the response of the baseline is in between the responses associated with the two types of fiscal adjustment. This result is consistent with Alesina and Ardagna (2012). On the other hand, tax-based fiscal adjustments have a contractionary and statistically significant effect on GDP with a peak negative effect of $-0.68 \%$ and on private consumption with a peak negative effect of $-0.71 \%$ within three years. When the composition of fiscal adjustment is classified into three types, as shown in column (2) of Fig. 4, the results do not differ much. While the results for mixed adjustments are almost the same as the baseline, pure taxbased fiscal adjustments decrease GDP significantly whereas pure spending-based fiscal adjustments appear contractionary but the effect is not statistically significant even in the year of fiscal adjustment.

An alternative way is to identify fiscal adjustments based on large changes of fiscal variables rather than by looking at changes of fiscal balance: as an increase in cyclically-adjusted revenues or a decrease in cyclically-adjusted spending. Although this method is different from the conventional method based on fiscal balance, it has several advantages. First, we can capture some episodes of fiscal adjustment which might be otherwise excluded. This is the case when the fiscal adjustment on spending (revenue) side is offset by a counter-balancing change of revenue (spending). Second, we can reduce the risk that the results are driven by a particular threshold (e.g. 50\%) chosen to identify tax-based and spending-based adjustments. Therefore, we re-identify fiscal adjustments based on large changes of cyclically-adjusted revenues and spending respectively. ${ }^{36}$ The former are denoted as 'tax side' and the latter denoted as 'spending side'. Then, we replace $\triangle F A$ in the baseline specification with these two types of fiscal adjustments to estimate their effects on GDP and private consumption.

\footnotetext{
${ }^{36}$ The definition for a fiscal adjustment on tax (spending) side follows the 4 criteria in Section 4, but uses changes of cyclicallyadjusted revenues (spending) instead of changes of CAPB. For example, as the criterion for a fiscal adjustment of a given year, tax (spending)-side adjustment is defined when the cyclically-adjusted revenue increases (decreases) by at least the average + standard deviation of the changes of cyclically-adjusted revenue (spending) for each country in 1 year.
} 


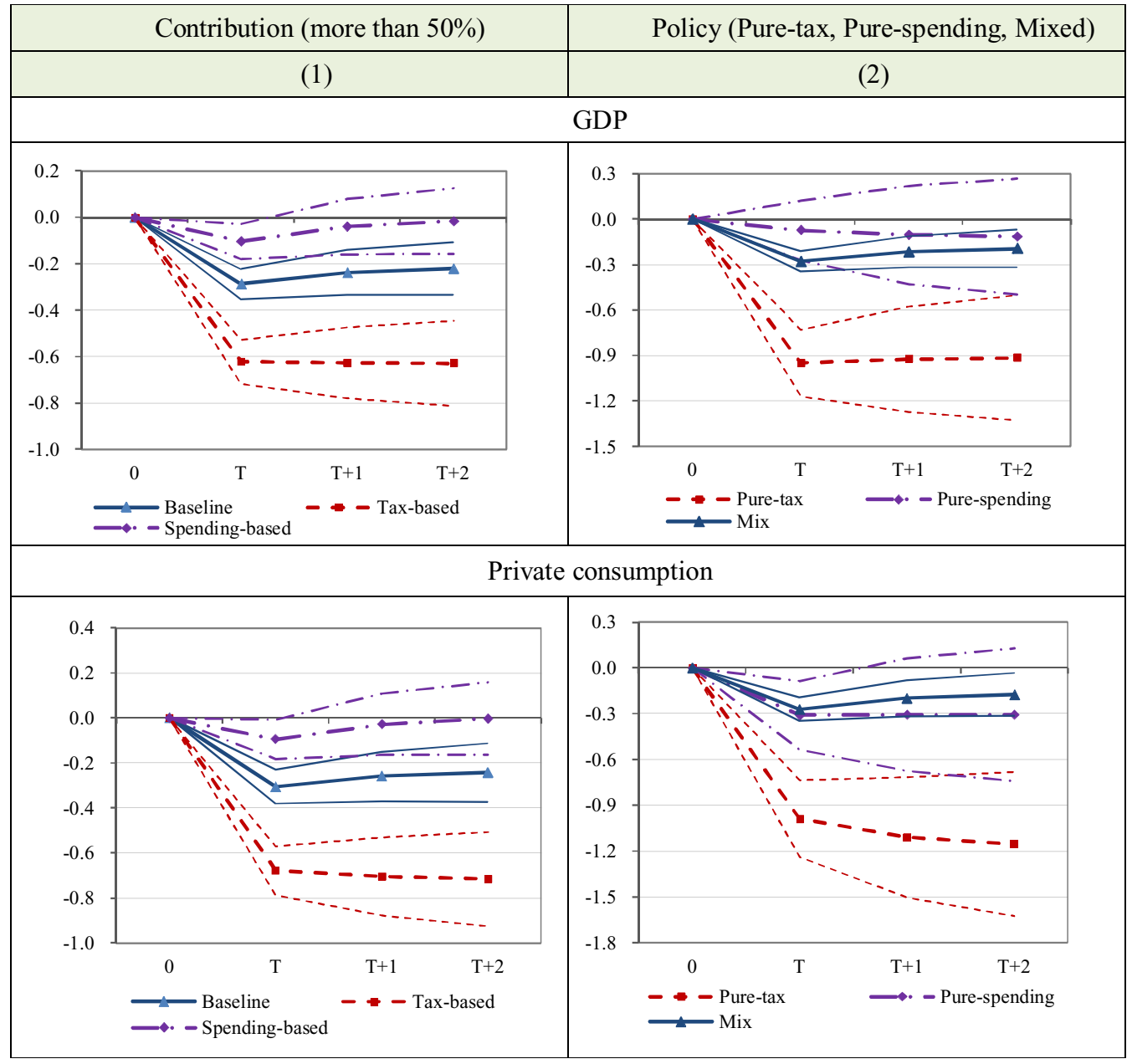

Fig. 4. The effects of the composition of fiscal adjustment.

Note: T denotes the year of fiscal adjustment. The figure reports point estimates and one standard error band. Tax-based means that the improvement in the CAPB for fiscal adjustment is by more than $50 \%$ due to the tax hikes. On the other hand, pure-tax indicates that the improvement in the CAPB is totally due to the tax hikes.

Fig. 5 shows the estimated effects of fiscal adjustment according to its composition. While fiscal adjustments based on an increase in revenues have a largely contractionary and statistically significant effect on GDP and private consumption, fiscal adjustments based on a decrease in spending have a small expansionary but not statistically significant effect on GDP and negligible effects on private consumption. Therefore, we still cannot find any firm evidence of expansionary effects even in the case of fiscal adjustment based on large spending-cuts. However, this reconfirms that spending-based adjustments are less contractionary than tax-based ones, which is consistent with the previous results of compositions of fiscal adjustment based on the CAPB.

Guajardo et al. (2014) argue that a possible reason for the different effects depending on the compositions of fiscal adjustment is that monetary policy is more favorable in case of spending cuts. They suggest that central banks conduct monetary stimulus more actively following spending cuts than after tax hikes so that the policy rate increases in response to tax hikes and decreases in response to 


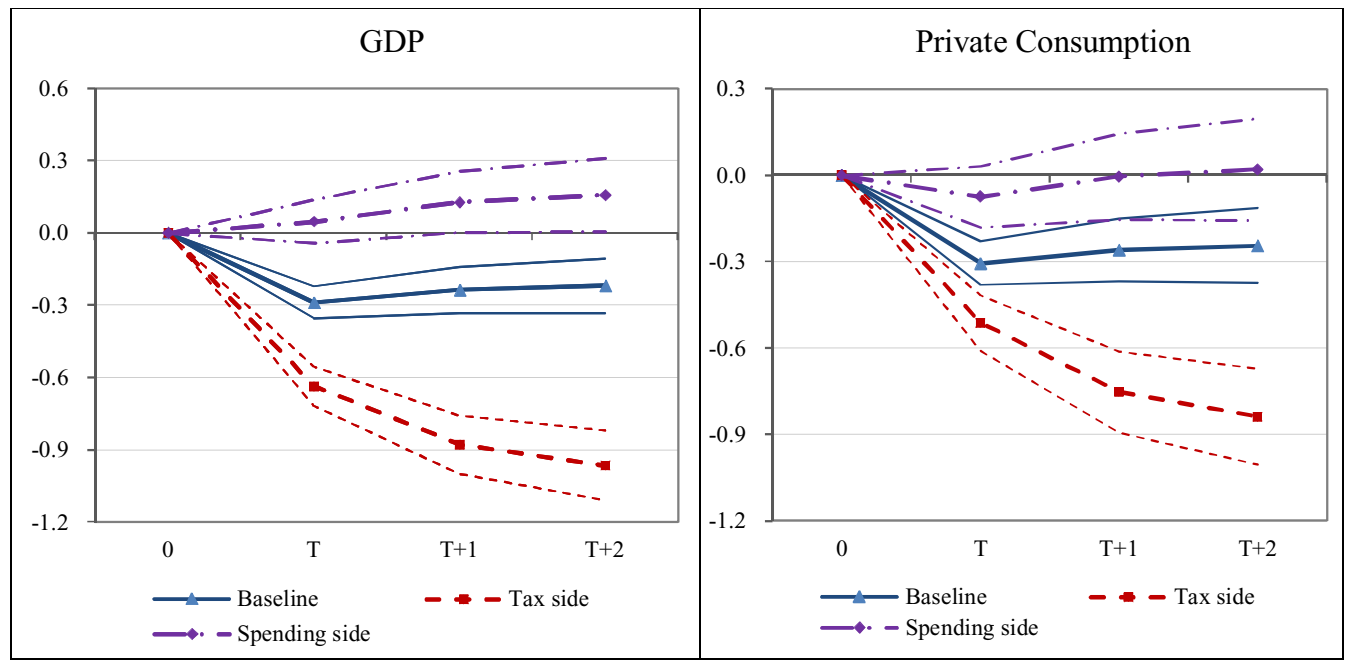

Fig. 5. The effects of composition of fiscal adjustment: Based on the changes in cyclically-adjusted revenues and spending. Note: T denotes the year of fiscal adjustment. The figure reports point estimates and one standard error bands. 'Tax side' means the fiscal adjustment based on large increases in cyclically-adjusted revenues and 'spending side' indicates the fiscal adjustment based on large decreases of cyclically-adjusted spending.

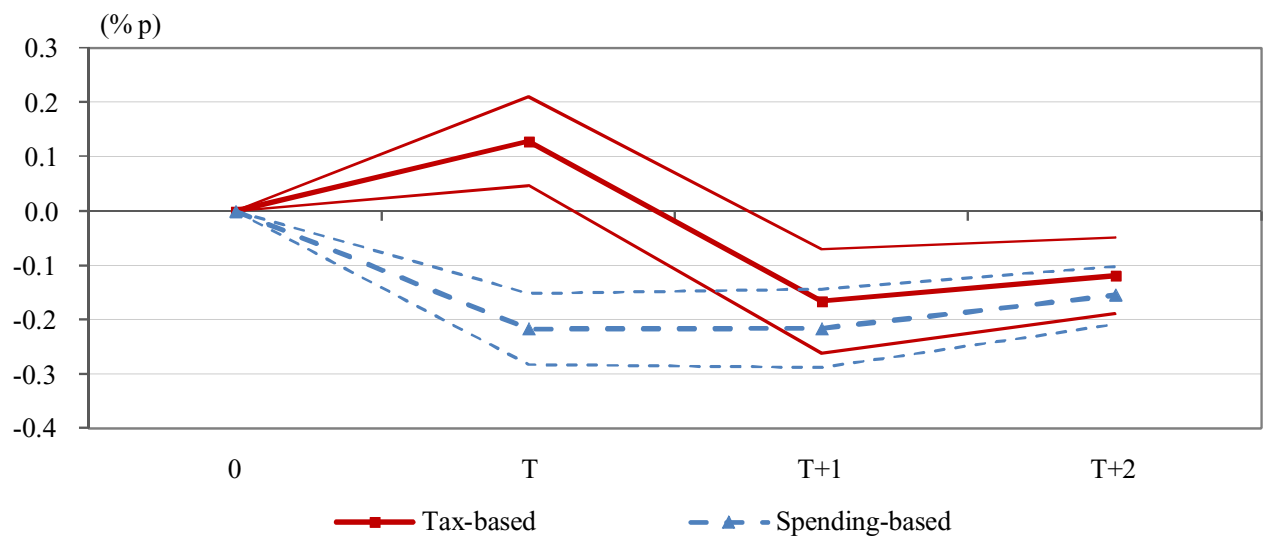

Fig. 6. Response of short-term interest rate to two compositions of fiscal adjustment.

Note: $\mathrm{T}$ denotes the year of fiscal adjustment. The figure reports point estimates and one standard error band.

spending cuts. ${ }^{37}$ Therefore, we investigate the response of short-term interest rate to the two types of fiscal adjustment. As Fig. 6 shows, the response of the short-term interest rate is significantly different according to the two types of fiscal adjustment only in the year of fiscal adjustment. After one year, the short term interest rate falls significantly in both cases. Therefore, this result can partially

\footnotetext{
37 Guajardo et al. (2014) contend that central banks prefer spending-based, rather than tax-based, fiscal adjustment because they interpret the former as a signal for a stronger commitment to fiscal discipline, but they are averse to an increase in taxes such as the indirect tax because of the possibility of subsequent high inflation, inducing the Central Bank to raise interest rates.
} 
Table 11

Effect of fiscal adjustment on growth: composition and policy variables.

\begin{tabular}{lrrrr}
\hline Variables & GDP growth & GDP growth & \multicolumn{1}{c}{ GDP growth } & \multicolumn{1}{c}{ GDP growth } \\
\hline GDP growth (T-1) & $0.354^{* * *}(0.040)$ & $0.374^{* * *}(0.040)$ & $0.373^{* * * *}(0.042)$ & $0.389^{* * * *}(0.041)$ \\
FA (T) & $-0.289^{* * *}(0.066)$ & & $-0.222^{* * *}(0.066)$ & \\
FA (T-1) & $0.153^{* *}(0.065)$ & & $0.131^{* *}(0.063)$ & $-0.532^{* * *}(0.098)$ \\
Tax-based (T) & & $-0.622^{* * *}(0.096)$ & & $0.222^{* * *}(0.099)$ \\
Tax-based (T-1) & $0.228^{* *}(0.100)$ & & $-0.053(0.077)$ \\
Spending-based (T) & & $-0.104(0.077)$ & & $0.075(0.070)$ \\
Spending-based (T-1) & & $0.103(0.073)$ & $-0.124^{* * *}(0.035)$ & $-0.102^{* * *}(0.035)$ \\
Short- term interest rate & & & $0.019(0.012)$ & $0.018(0.012)$ \\
Real effective exchange rate & & & $4.521^{* * *}(0.545)$ & $4.320^{* * *}(0.539)$ \\
Constant & $3.602^{* * *}(0.475)$ & $3.786^{* * *}(0.469)$ & 615 & 615 \\
Observations & 645 & 645 & 0.600 & 0.613 \\
R-squared & 0.564 & 0.580 & 20 & 20 \\
No. countries & 20 & 20 & &
\end{tabular}

Note: Standard errors in parentheses, ${ }^{* * *} \mathrm{p}<0.01,{ }^{* *} \mathrm{p}<0.05$.

support the argument of Guajardo et al. (2014) that the different effects depending on the composition of fiscal adjustment are ascribed to different monetary policy stances.

\subsection{The role of the economic environment}

Next, we check the robustness of our findings by including the short-term interest rate and the real effective exchange rate among the regressors. ${ }^{38}$ These two additional control variables are aimed at accounting for monetary policy and exchange rate policy respectively. Table 11 and Fig. 7 show the results. The fit of the regression improves when we include variables relating to the economic policy. The coefficient of fiscal adjustment, as well as that for tax-based adjustment, remains significantly negative, although they are smaller than those without controlling for policy variables. Similarly, spending-based fiscal adjustment has a smaller negative coefficient, but is still statistically insignificant. The change of effects can be attributed to monetary policy in that the short-term interest rate has a significantly negative effect on growth, as expected, but the exchange rate is not significant. Fig. 7 confirms that fiscal adjustments have less contractionary effect on GDP when we control for monetary policy than in the baseline. Therefore, monetary policy can affect the response of GDP to fiscal adjustment shocks. If the short-term interest rate falls, it leads to an increase in GDP. Therefore, if fiscal adjustment coincides with a large reduction in the short-term interest rate, this may stimulate the economy in the following periods. However, even in this case, this result is to be attributed not to the fiscal adjustment, but to the lax monetary policy. In regard to the effects of composition of fiscal adjustment, Fig. 7 shows that the response of GDP is larger in tax-based fiscal adjustments than in spendingbased ones. Therefore, as Fig. 6 in the previous subsection shows, if the discretionary monetary policy responds differently according to the type of fiscal adjustment, this could help account for the different effects depending on the composition of fiscal adjustment. However, it cannot be a decisive factor, contrary to the argument of Guajardo et al. (2014), in that when we control for the short-term interest rate, there is still a large difference between the effects of tax-based and spending-based fiscal adjustment on GDP.

Furthermore, there can be other omitted factors that are likely to influence the effects of fiscal adjustment on economic activity. The omission of relevant variables could bias the response of output in estimating the effects of fiscal adjustments. Therefore, we add additional variables into the baseline model one by one. The initial government debt is considered because a high debt level can lead to expansionary fiscal adjustment via the wealth effect. International factors such as the exchange rate

\footnotetext{
${ }^{38}$ Nominal short term interest rate is obtained from OECD Economic Outlook No.88. Real effective exchange rate is drawn from international finance statistics of the Bank for International Settlements. When using the real interest rate calculated using GDP deflator, the result is not affected.
} 


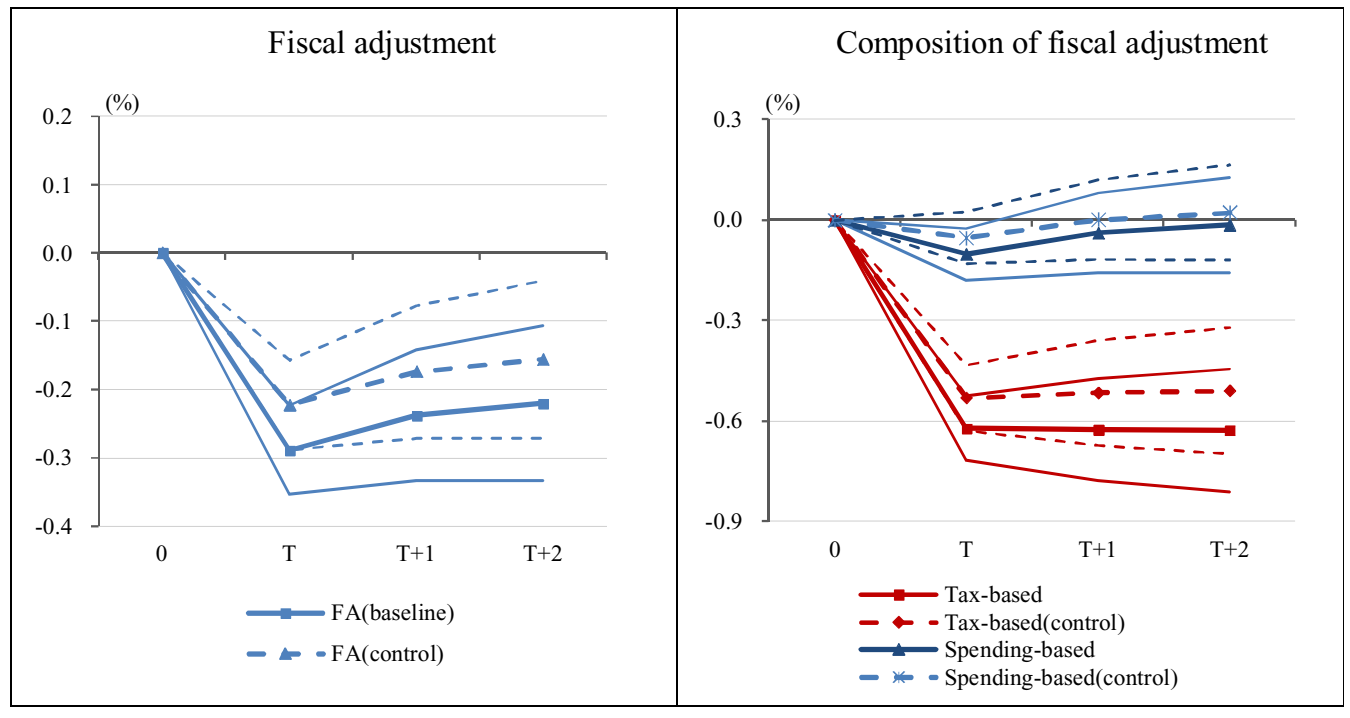

Fig. 7. The effects of fiscal adjustment on GDP.

Note: $\mathrm{T}$ denotes the year of fiscal adjustment. The figure reports point estimates and one standard error band.

regime and financial openness can be taken into account as another potential factor. Furthermore, Ilzetzki et al. (2011) find that the degrees of exchange rate flexibility and openness to current and capital account transactions are critical determinants of the size of fiscal multiplier. Therefore, we include the exchange rate regime and financial openness index. ${ }^{39}$ We also include dummies for Euro Area membership and for participation in IMF programs. Political environment can similarly play a role and therefore we include a dummy for countries with a federal system of government and a measure of ruling party ideology (the latter is obtained from Potrafke, 2009). Finally, we also include lagged inflation and the long-term interest rate as two potentially important macroeconomic variables.

Tables 12 and 13 show the regression results obtained when we control for the impact of these additional factors. The results are very similar to the baseline results, as is clear from column (10) of Table 12, where all the variables are included in the same regression. Here GDP growth (T-1), $\Delta \mathrm{FA}(\mathrm{T})$ and $\triangle F A(T-1)$ remain highly significant, as in the baseline, and the signs as well as magnitudes of their coefficients remain remarkably similar. Moreover, all of the additional controls turn out insignificant in column (10), with the exception of gross debt, inflation and long-term interest rates, all of which have a negative effect on growth, which is intuitive. As regards columns (1)-(9), where one variable at a time is added to the baseline, we find that only the exchange rate regime and the long-term interest rate are significant.

Aside from the fairly comprehensive list of variables considered, regulatory reform such as labor and product market institutions, and structural reforms should be considered as significant and relevant factors influencing the estimated effects of fiscal adjustment on economic activity. Several studies investigate the interactions between fiscal adjustment and these market institutions and structural reforms and show that these regulatory policies can play a significant role in initiating fiscal adjustment and determining its success (Guichard et al., 2007; Hauptmeier et al., 2006; Tagkalakis,

\footnotetext{
${ }^{39}$ For exchange rate regime, we use the IMF official classification from Ilzetzki et al. (2009) to determine the exchange rate regime of each country in every year and construct a binary variable that takes the value of 1 for the fixed regime and 0 for the flexible regime, following Ilzetzki et al. (2011). For financial openness index, we use the KAOPEN index based on restrictions on cross-border financial transactions from Chinn and Ito (2008).
} 
Table 12

Effect of fiscal adjustment on growth: controlling for other factors.

\begin{tabular}{|c|c|c|c|c|c|c|c|c|c|c|c|}
\hline Variables & Baseline & (1) & $(2)$ & (3) & (4) & (5) & (6) & (7) & (8) & (9) & $(10)$ \\
\hline GDP growth (T-1) & $\begin{array}{l}0.354^{* * * *} \\
(0.040)\end{array}$ & $\begin{array}{l}0.387^{* * *} \\
(0.042)\end{array}$ & $\begin{array}{l}0.348^{* * * *} \\
(0.040)\end{array}$ & $\begin{array}{l}0.354^{* * *} \\
(0.040)\end{array}$ & $\begin{array}{l}0.356^{* * * *} \\
(0.040)\end{array}$ & $\begin{array}{l}0.354^{* * *} \\
(0.040)\end{array}$ & $\begin{array}{l}0.354^{* * *} \\
(0.040)\end{array}$ & $\begin{array}{l}0.354^{* * *} \\
(0.040)\end{array}$ & $\begin{array}{l}0.349^{* * *} \\
(0.040)\end{array}$ & $\begin{array}{l}0.347^{* * *} \\
(0.040)\end{array}$ & $\begin{array}{l}0.346^{* * * *} \\
(0.043)\end{array}$ \\
\hline$\Delta \mathrm{FA}(\mathrm{T})$ & $\begin{array}{l}-0.289^{* * * *} \\
(0.066)\end{array}$ & $\begin{array}{l}-0.280^{* * *} \\
(0.066)\end{array}$ & $\begin{array}{l}-0.302^{* * * *} \\
(0.066)\end{array}$ & $\begin{array}{l}-0.291^{* * * *} \\
(0.066)\end{array}$ & $\begin{array}{l}-0.290^{* * * *} \\
(0.066)\end{array}$ & $\begin{array}{l}-0.291^{* * * *} \\
(0.066)\end{array}$ & $\begin{array}{l}-0.288^{* * * *} \\
(0.066)\end{array}$ & $\begin{array}{l}-0.289^{\text {***** }} \\
(0.066)\end{array}$ & $\begin{array}{l}-0.291^{* * *} \\
(0.066)\end{array}$ & $\begin{array}{l}-0.260^{* * *} \\
(0.066)\end{array}$ & $\begin{array}{l}-0.249^{* * * *} \\
(0.068)\end{array}$ \\
\hline$\Delta \mathrm{FA}(\mathrm{T}-1)$ & $\begin{array}{c}0.153^{* *} \\
(0.065)\end{array}$ & $\begin{array}{c}0.146^{* * *} \\
(0.065)\end{array}$ & $\begin{array}{c}0.142 * * \\
(0.065)\end{array}$ & $\begin{array}{c}0.152^{* *} \\
(0.065)\end{array}$ & $\begin{array}{c}0.151^{* *} \\
(0.065)\end{array}$ & $\begin{array}{c}0.152^{* *} \\
(0.065)\end{array}$ & $\begin{array}{c}0.152^{* *} \\
(0.065)\end{array}$ & $\begin{array}{c}0.153^{* *} \\
(0.065)\end{array}$ & $\begin{array}{c}0.152^{* *} \\
(0.065)\end{array}$ & $\begin{array}{l}0.172^{* * * *} \\
(0.065)\end{array}$ & $\begin{array}{l}0.173^{* * * *} \\
(0.066)\end{array}$ \\
\hline Gross debt (T-1) & & $\begin{array}{l}-0.001 \\
(0.004)\end{array}$ & & & & & & & & & $\begin{array}{l}-0.008^{*} \\
(0.005)\end{array}$ \\
\hline Exchange rate regime (Fixed) & & & $\begin{array}{l}-0.436^{* *} \\
(0.218)\end{array}$ & & & & & & & & $\begin{array}{l}-0.254 \\
(0.237)\end{array}$ \\
\hline Financial openness & & & & $\begin{array}{c}0.148 \\
(0.100)\end{array}$ & & & & & & & $\begin{array}{c}0.165 \\
(0.120)\end{array}$ \\
\hline Euro area $^{a}$ & & & & & $\begin{array}{l}-0.200 \\
(0.447)\end{array}$ & & & & & & $\begin{array}{l}-0.208 \\
(0.286)\end{array}$ \\
\hline IMF program $(\mathrm{T}-1)^{\mathrm{b}}$ & & & & & & $\begin{array}{c}0.239 \\
(0.442)\end{array}$ & & & & & $\begin{array}{l}-0.020 \\
(0.466)\end{array}$ \\
\hline Federal system & & & & & & & $\begin{array}{l}-0.566 \\
(0.842)\end{array}$ & & & & $\begin{array}{l}-0.617 \\
(0.830)\end{array}$ \\
\hline Ruling party's ideology ${ }^{c}$ & & & & & & & & $\begin{array}{l}-0.003 \\
(0.079)\end{array}$ & & & $\begin{array}{c}0.034 \\
(0.083)\end{array}$ \\
\hline Inflation (T-1) & & & & & & & & & $\begin{array}{l}-0.011 \\
(0.009)\end{array}$ & & $\begin{array}{l}-0.027^{* *} \\
(0.012)\end{array}$ \\
\hline Long-term interest rate (T-1) & & & & & & & & & & $\begin{array}{l}-0.098^{* *} \\
(0.044)\end{array}$ & $\begin{array}{l}-0.155^{* * * *} \\
(0.059)\end{array}$ \\
\hline Constant & $\begin{array}{l}3.602^{* * * *} \\
(0.475)\end{array}$ & $\begin{array}{l}-0.117 \\
(0.550)\end{array}$ & $\begin{array}{l}3.890^{* * * *} \\
(0.495)\end{array}$ & $\begin{array}{c}0.526 \\
(0.529)\end{array}$ & $\begin{array}{l}3.602^{* * *} \\
(0.475)\end{array}$ & $\begin{array}{c}0.294 \\
(0.521)\end{array}$ & $\begin{array}{l}3.804^{* * * *} \\
(0.562)\end{array}$ & $\begin{array}{l}3.611^{\text {**** }} \\
(0.538)\end{array}$ & $\begin{array}{c}-2.436^{* *} \\
(1.105)\end{array}$ & $\begin{array}{l}4.740^{* * * *} \\
(0.611)\end{array}$ & $\begin{array}{c}0.601 \\
(1.582)\end{array}$ \\
\hline Observations & 645 & 609 & 645 & 639 & 645 & 645 & 645 & 645 & 645 & 644 & 602 \\
\hline R-squared & 0.564 & 0.593 & 0.567 & 0.567 & 0.564 & 0.564 & 0.564 & 0.564 & 0.565 & 0.569 & 0.607 \\
\hline No. countries & 20 & 20 & 20 & 20 & 20 & 20 & 20 & 20 & 20 & 20 & 20 \\
\hline
\end{tabular}

Note: Standard errors in parentheses, ${ }^{* * *} \mathrm{p}<0.01,{ }^{* *} \mathrm{p}<0.05,{ }^{*} \mathrm{p}<0.1$.

aThe dummy variable takes the value 1 for the countries that were members of the Euro zone in 1999 and afterwards, and 0 otherwise.

bThe dummy variable takes the value 1 for the countries under IMF programs such as SBA, EFF, SAF, and ESAF, and 0 otherwise.

'Party ideology takes values from 1 to 5 , with 1-2 reserved for right-wing governments, 4-5 for left wing ones and 3 used for central or mixed ones. Source: Potrafke (2009). 
Table 13

Response of GDP to a fiscal adjustment shock of $1 \%$ of GDP.

\begin{tabular}{|c|c|c|c|c|c|c|c|c|c|c|c|}
\hline \multirow[t]{2}{*}{$\begin{array}{l}\text { Control } \\
\text { variable }\end{array}$} & \multirow[t]{2}{*}{ Baseline } & \multirow{2}{*}{$\begin{array}{l}\text { Gross debt } \\
(1)\end{array}$} & \multirow{2}{*}{$\begin{array}{l}\text { Exchange } \\
\text { rate } \\
\text { regime } \\
(2)\end{array}$} & \multirow{2}{*}{$\begin{array}{l}\text { Financial } \\
\text { openness } \\
(3)\end{array}$} & \multirow{2}{*}{$\begin{array}{l}\text { Euro area } \\
(4)\end{array}$} & \multirow{2}{*}{$\begin{array}{l}\text { IMF } \\
\text { programs } \\
(5)\end{array}$} & \multirow{2}{*}{$\begin{array}{l}\begin{array}{l}\text { Federal } \\
\text { system }\end{array} \\
(6)\end{array}$} & \multirow{2}{*}{$\begin{array}{l}\begin{array}{l}\text { Party's } \\
\text { ideology }\end{array} \\
(7)\end{array}$} & \multirow{2}{*}{$\begin{array}{l}\text { Inflation } \\
(8)\end{array}$} & \multirow{2}{*}{$\begin{array}{l}\text { Long-term } \\
\text { interest } \\
\text { rate } \\
(9)\end{array}$} & \multirow{2}{*}{$\begin{array}{l}\text { All (1-9) } \\
\overline{(10)}\end{array}$} \\
\hline & & & & & & & & & & & \\
\hline $\mathrm{T}$ & $\begin{array}{l}-0.289^{* * * *} \\
(0.066)\end{array}$ & $\begin{array}{l}-0.280^{* * * *} \\
(0.066)\end{array}$ & $\begin{array}{l}-0.302^{* * * *} \\
(0.066)\end{array}$ & $\begin{array}{l}-0.290^{* * * *} \\
(0.066)\end{array}$ & $\begin{array}{l}-0.290^{* * * *} \\
(0.066)\end{array}$ & $\begin{array}{l}-0.291^{* * * *} \\
(0.066)\end{array}$ & $\begin{array}{l}-0.288^{* * *} \\
(0.066)\end{array}$ & $\begin{array}{l}-0.289^{* * * *} \\
(0.066)\end{array}$ & $\begin{array}{l}-0.291^{* * * *} \\
(0.066)\end{array}$ & $\begin{array}{l}-0.260^{* * * *} \\
(0.066)\end{array}$ & $\begin{array}{l}-0.249^{* * * *} \\
(0.068)\end{array}$ \\
\hline $\mathrm{T}+1$ & $\begin{array}{l}-0.238^{* *} \\
(0.096)\end{array}$ & $\begin{array}{l}-0.241^{* *} \\
(0.100)\end{array}$ & $\begin{array}{l}-0.264^{* * * *} \\
(0.097)\end{array}$ & $\begin{array}{l}-0.243^{* *} \\
(0.097)\end{array}$ & $\begin{array}{l}-0.242^{* *} \\
(0.097)\end{array}$ & $\begin{array}{l}-0.242^{* *} \\
(0.097)\end{array}$ & $\begin{array}{l}-0.237^{* *} \\
(0.096)\end{array}$ & $\begin{array}{l}-0.238^{* *} \\
(0.096)\end{array}$ & $\begin{array}{l}-0.241^{* *} \\
(0.096)\end{array}$ & $\begin{array}{c}-0.178^{*} \\
(0.097)\end{array}$ & $\begin{array}{c}-0.162 \\
(0.104)\end{array}$ \\
\hline $\mathrm{T}+2$ & $\begin{array}{c}-0.220^{*} \\
(0.114)\end{array}$ & $\begin{array}{c}-0.226^{*} \\
(0.120)\end{array}$ & $\begin{array}{l}-0.251^{* *} \\
(0.114)\end{array}$ & $\begin{array}{l}-0.226^{* * *} \\
(0.114)\end{array}$ & $\begin{array}{l}-0.225^{* *} \\
(0.114)\end{array}$ & $\begin{array}{l}-0.225^{* *} \\
(0.114)\end{array}$ & $\begin{array}{c}-0.219^{*} \\
(0.114)\end{array}$ & $\begin{array}{c}-0.220^{*} \\
(0.114)\end{array}$ & $\begin{array}{l}-0.223^{* * *} \\
(0.113)\end{array}$ & $\begin{array}{c}-0.150 \\
(0.116)\end{array}$ & $\begin{array}{l}-0.132 \\
(0.124)\end{array}$ \\
\hline
\end{tabular}

Note: The table shows the point estimate responses of GDP to a shock of fiscal adjustment equal to $1 \%$ of GDP. T denotes the year of fiscal adjustment. The standard errors in parentheses are computed via the delta method, ${ }^{* * *} \mathrm{p}<0.01,{ }^{* *} \mathrm{p}<0.05,{ }^{*} \mathrm{p}<0.1$ 
2009)..$^{40}$ However, when these are controlled for, the qualitative effects on economic activity of fiscal adjustment does not change (Alesina and Ardagna, 2012; Hernández de Cos and Moral-Benito, 2011). Although we do not address the effects of labor and product market institutions and structural reforms during the fiscal adjustment episode in this paper, they can affect the responses of output to fiscal adjustment in the long term as well as quantitatively via employment and investment behavior.

\subsection{Effects of fiscal adjustment across country groups}

The effects of fiscal adjustment on the economic activity may be different according to the sensitivity of private agents, which in turn depend on the past trajectory of fiscal policy. While our definition of fiscal adjustment controls for country-specific heterogeneity, in this subsection, we explore this issue further by dividing the 20 countries into two groups on the basis of two criteria: the frequency of fiscal adjustments and the volatility of discretionary fiscal policy. For the first criterion, high and low frequency groups include 10 countries each. Similarly, high and low fluctuation groups each consist of 10 countries according to the standard deviation of changes in the CAPB. ${ }^{41}$

Table 14 reports the estimated responses of GDP and private consumption to a fiscal adjustment shock. Interestingly, for the high group in terms of both frequency and fluctuation, economic activity displays a significantly negative response only in the year of fiscal adjustment. On the other hand, the low groups in frequency and fluctuation alike display a strong response to fiscal adjustment in all years. This finding supports the notion that economic agents respond more sensitively to unexpected or unusual shocks. When fiscal policy undergoes frequent changes, agents become accustomed to such changes and their responses become smaller.

\section{Conclusions}

This paper investigates the short-term macroeconomic effects of fiscal adjustment in 20 OECD countries over the period 1970-2009. This issue has been studied in many previous contributions already. Recently, it has become more central in academic and policy circles due to the rising fiscal deficits and public debts during the current global crisis. Much of the literature argues that fiscal adjustments can promote economic output even in the short term. However, after identifying fiscal adjustment episodes from historical documents, Guajardo et al. (2014) conclude that fiscal adjustments are always contractionary. They also criticize the CAPB-based measures used in the rest of literature as being imprecise and biased toward overstating the potential expansionary effects of fiscal adjustments.

This paper reconsiders the CAPB-based measure in order to identify the fiscal adjustment episodes more accurately, taking into account the problems identified by Guajardo et al. (2014). The main features of our new measure of fiscal adjustment are as follows. First, we consider the effect of asset price fluctuations on tax revenues when cyclically correcting the fiscal balance. Second, our criteria for selecting fiscal adjustment episodes allow for the heterogeneity of individual countries in fiscal policy, contrary to the uniform approach in the previous literature. Third, our criteria account for temporary one-off transactions and temporary adverse shocks which can undermine the accuracy of the CAPB. Although Guajardo et al. (2014) argue that the CAPB is an unreliable guide regarding fiscal adjustment, our new criteria identify fiscal adjustment episodes that largely overlap with their narrativebased ones.

Based on the fiscal adjustments identified, we estimate the effects of fiscal adjustment on economic activity. Our key result is that a fiscal adjustment has contractionary effects on economic activity in the short term. This provides little support for the expansionary fiscal adjustment hypothesis: such 'non-Keynesian effects' are very limited and probably occur only under specific conditions, not generally. This is consistent with the results of Guajardo et al. (2014). As for the role of the composition

\footnotetext{
40 Tagkalakis (2009) shows that a reduction in the unemployment benefit replacement rate, weak bargaining coordination and centralization of union increase the likelihood of initiating and of successfully concluding a fiscal adjustment, but more flexible employment protection legislation and product market regulation work in the opposite direction.

${ }^{41}$ Further details and the list of countries in each group are available upon request.
} 
Table 14

Effects of fiscal adjustment across country groups.

\begin{tabular}{|c|c|c|c|c|c|c|c|c|c|c|}
\hline \multirow{3}{*}{$\begin{array}{l}\text { Variable } \\
\text { Group }\end{array}$} & \multicolumn{5}{|l|}{ GDP } & \multicolumn{5}{|c|}{ Private consumption } \\
\hline & \multirow[t]{2}{*}{ Baseline } & \multicolumn{2}{|l|}{ Frequency } & \multicolumn{2}{|c|}{ Fluctuation } & \multirow[t]{2}{*}{ Baseline } & \multicolumn{2}{|l|}{ Frequency } & \multicolumn{2}{|c|}{ Fluctuation } \\
\hline & & High & Low & High & Low & & High & Low & High & Low \\
\hline $\mathrm{T}$ & $\begin{array}{l}-0.289^{* * * *} \\
(0.066)\end{array}$ & $\begin{array}{c}-0.151^{*} \\
(0.081)\end{array}$ & $\begin{array}{l}-0.413^{* * *} \\
(0.115)\end{array}$ & $\begin{array}{c}-0.166^{* *} \\
(0.081)\end{array}$ & $\begin{array}{l}-0.571^{* * *} \\
(0.125)\end{array}$ & $\begin{array}{l}-0.305^{* * *} \\
(0.075)\end{array}$ & $\begin{array}{c}-0.137^{*} \\
(0.085)\end{array}$ & $\begin{array}{l}-0.493^{* * * *} \\
(0.139)\end{array}$ & $\begin{array}{l}-0.097 \\
(0.085)\end{array}$ & $\begin{array}{l}-0.737^{* * * *} \\
(0.155)\end{array}$ \\
\hline $\mathrm{T}+1$ & $\begin{array}{c}-0.238^{* *} \\
(0.096)\end{array}$ & $\begin{array}{c}-0.071 \\
(0.122)\end{array}$ & $\begin{array}{c}-0.414^{* *} \\
(0.165)\end{array}$ & $\begin{array}{l}-0.130 \\
(0.128)\end{array}$ & $\begin{array}{c}-0.450^{* *} \\
(0.170)\end{array}$ & $\begin{array}{l}-0.260^{* *} \\
(0.110)\end{array}$ & $\begin{array}{c}-0.085 \\
(0.134)\end{array}$ & $\begin{array}{l}-0.522^{* * *} \\
(0.190)\end{array}$ & $\begin{array}{c}-0.006 \\
(0.137)\end{array}$ & $\begin{array}{l}-0.682^{* * *} \\
(0.212)\end{array}$ \\
\hline $\mathrm{T}+2$ & $\begin{array}{l}-0.220^{*} \\
(0.114)\end{array}$ & $\begin{array}{c}-0.046 \\
(0.143)\end{array}$ & $\begin{array}{l}-0.414^{* *} \\
(0.195)\end{array}$ & $\begin{array}{l}-0.112 \\
(0.161)\end{array}$ & $\begin{array}{l}-0.427^{* *} \\
(0.187)\end{array}$ & $\begin{array}{c}-0.244^{*} \\
(0.130)\end{array}$ & $\begin{array}{c}-0.064 \\
(0.163)\end{array}$ & $\begin{array}{l}-0.531^{* *} \\
(0.216)\end{array}$ & $\begin{array}{c}0.042 \\
(0.176)\end{array}$ & $\begin{array}{l}-0.670^{* * * *} \\
(0.233)\end{array}$ \\
\hline Observations & 645 & 336 & 309 & 330 & 315 & 645 & 336 & 309 & 330 & 315 \\
\hline R-squared & 0.564 & 0.605 & 0.586 & 0.627 & 0.576 & 0.420 & 0.478 & 0.443 & 0.559 & 0.374 \\
\hline $\begin{array}{l}\text { No. } \\
\text { countries }\end{array}$ & 20 & 10 & 10 & 10 & 10 & 20 & 10 & 10 & 10 & 10 \\
\hline
\end{tabular}

Note: $\mathrm{T}$ denotes the year of fiscal adjustment. Standard errors in parentheses are computed via the delta method, ${ }^{* * *} \mathrm{p}<0.01,{ }^{* *} \mathrm{p}<0.05,{ }^{*} \mathrm{p}<0.1$. 
of fiscal adjustment, spending-based fiscal adjustments lead to smaller reductions of output than taxbased fiscal adjustments. This finding is in line with most of the literature regardless of the approach used.

Further work could explore in more depth the effects of fiscal adjustments. First, as for the reasons behind the different effects of tax-based and spending-based adjustments, more detailed disaggregation of fiscal spending and taxes could be used for the analysis. Second, most of the literature on fiscal policy has studied developed countries such as the OECD because of data limitations. However, as the data for developing countries have become more easily available lately, the fiscal adjustment in developing countries also needs to be investigated for the comparison with developed countries' results. Another possible extension would address the anticipation effects by private agents through comparing the narrative data based on announced plans with the CAPB-based data based on actual outcomes. However, to capture the timing of fiscal adjustment accurately, quarterly rather than annual data may be required.

\section{References}

Afonso, A., 2010. Expansionary fiscal consolidation in Europe: new evidence. Appl. Econ. Lett. 17, 105-109.

Afonso, A., Nickel, C., Rother, P., 2006. Fiscal consolidations in the central and eastern European countries. Kiel Institute 402-421.

Ahrend, R., Catte, P., Price, R., 2006. Interactions between monetary and fiscal policy: how monetary conditions affect fiscal consolidation. OECD working papers, 49.

Alesina, A., Ardagna, S., 1998. Tales of fiscal adjustment. Econ. Policy 27, 489-545.

Alesina, A., Ardagna, S., 2010. Large changes in fiscal policy: taxes versus spending. Tax Policy and the Economy 24, 35-68.

Alesina, A., Ardagna, S., 2012. The design of fiscal adjustments. NBER working paper, 18423.

Alesina, A., Ardagna, S., Perotti, R., 2002. Fiscal policy, profits, and investment. American Economic Review 92 (3), $571-589$.

Alesina, A., Perotti, R., 1995. Fiscal expansion and adjustments in OECD countries. Econ. Policy 21, 5-248.

Alesina, A., Perotti, R., 1997. Fiscal adjustments in OECD countries: composition and macroeconomic effects. IMF Staff Pap. 2, $210-248$.

Alesina, A., Campante, F.R., Tabellini, G., 2008. Why is fiscal policy often procyclical? J. Eur. Econ. Assoc. 6 (5), 1006-1036.

Ardagna, S., 2004. Fiscal stabilizations: when do they work and why. Eur. Econ. Rev. 48, 1047-1074.

Ardagna, S., 2009. Financial markets' behavior around episodes of large changes in the fiscal stance. Eur. Econ. Rev. 53, 37-55.

Ardanaz, M., Corbacho, A., Gonzales, A., Tolsa, N., 2015. Structural fiscal balances in LAC: new dataset and estimations. IADB. Working Paper.

Bertola, G., Drazen, A., 1993. Trigger points and budget cuts: explaining the effects of fiscal austerity. Am. Econ. Rev. 83, 11-26.

Biorn, E., Klette, T.J., 1999. The labour input response to permanent changes in output: an errors-in-variables analysis based on panel data. Scand. J. Econ. 101 (3), 379-404.

Blanchard, O.J., 1990. Comments on Giavazzi and Pagano (90). NBER Macroecon. Annu. 5, 111-116.

Blanchard, O.J., 1993. Suggestion for a new set of fiscal indicators. OECD Economic Department working paper 79.

Burger, A., Zagler, M., 2008. US growth and budget consolidation in the 90s: was there a non-Keynesian effects? Int. Econ. \& Econ. Policy 5, 225-235.

Chinn, M.D., Ito, H., 2008. A new measure of financial openness. Journal of comparative policy analysis 10 (3), 309-322.

Devries, P., Guajardo, J., Leigh, D., Pescatori, A., 2011. A new action-based dataset of fiscal consolidation. IMF working paper, $11 / 128$.

Eschenbach, F., Schuknecht, L., 2002. Asset prices and fiscal balances. European Central Bank working paper, 141.

Feldstein, M., 1982. Government deficits and aggregate demand. J. Monet. Econ. 9, 1-20.

Giavazzi, F., Pagano, M., 1990. Can severe fiscal contraction be expansionary? Tales of two small European countries. NBER Macroecon. Annu. 5, 75-111.

Giavazzi, F., Pagano, M., 1996. Non-Keynesian effects of fiscal policy changes: international evidence and the Swedish experience. Swedish Economic Policy Review, Vol. 3, No.1, 67-103.

Giavazzi, F., Jappelli, T., Pagano, M., 2000. Searching for non-linear effects of fiscal policy: evidence from industrial and developing countries. Eur. Econ. Rev. 44, 1259-1289.

Giudice, G., Turrini, A., Veld, J.I., 2007. Non-Keynesian fiscal adjustment? A close look at expansionary fiscal consolidations in the EU. Open Econ. Rev. 18, 613-630.

Guajardo, J., Leigh, D., Pescatori, A., 2014. Expansionary austerity: international evidence. J. Eur. Econ. Assoc. 12 (4), $949-968$.

Guichard, S., Kennedy, M., Wurzel, E., André, C., 2007. What promotes fiscal consolidation: OECD country experiences. OECD working papers, 13.

Hauptmeier, S., Martin, H., Ludger, S., 2006. Expenditure reform in Industrialized Countries: a Case Study Approach, ECB Working Paper No. 634.

Hernández de Cos, P., Moral-Benito, E., 2011. Endogenous fiscal consolidations. Bank of Spain working paper, 1102.

Ilzetzki, E., Reinhart, C., Rogoff, K., 2009. Exchange rate arrangements entering the 21st century: which anchor will hold. Manuscript.

Ilzetzki, E., Mendoza, E.G., Végh, C.A., 2011. How big (small?) are fiscal multipliers? IMF working paper 11/52.

IMF, 2010. Will it hurt? Macroeconomic effects of fiscal consolidation. World Economic Outlook Ch.3, October.

Kamps, C., 2006. Are the effects of fiscal policy really nonlinear? A note. Empirica 33, 113-125.

Klomp, J., Hann, J.D., 2013. Do political budget cycles really exist? Appl. Econ. 45 (3), 329-341.

McDermott, C.J., Wescott, R.F., 1996. An empirical analysis of fiscal adjustment. IMF Staff Pap. 4, 725-753. 
Morris, R., Schuknecht, L., 2007. Structural balances and revenue windfalls: the role of asset prices. European Central Bank working paper, 737.

Oehlert, G.W., 2008. A note on the delta method. Am. Stat. 46 (1), 27-29.

Park, H., Song, H., 2010. Current and Future Tasks for Desirable Fiscal Consolidation Policy. Korea Institute of Public Finance, Sejong, Korea.

Potrafke, N., 2009. Did globalization restrict partisan politics? An empirical evaluation of social expenditures in a panel of OECD countries. Public Choice 140, 105-124.

Price, R., Dang, T., 2011. Adjusting fiscal balances for asset price cycles. OECD working paper, 868.

Reinhart, C.M., Rogoff, K.S., 2009. The aftermath of financial crises. Am. Econ. Rev. 99 (2), 466-472.

Riera-Crichton, D., Vegh, C.A., Vuletin, G., 2012. Tax multipliers: pitfalls in measurement and identification. NBER Working Paper No. 18497.

Romer, C., Romer, D., 2010. The macroeconomic effects of tax changes: estimates based on a new measure of fiscal shocks. Am. Econ. Rev. 100, 763-801.

Roodman, D., 2006. How to do xtabond2: an introduction to ‘difference’ and ‘system’ GMM in Stata. Center for Global Development working paper, 103.

Schaffer, M.E., 2010. Xtivreg2: Stata module to perform extended IV/2SLS, GMM and AC/HAC, LIML and k-class regression for panel data models. <http://ideas.repec.org/c/boc/bocode/s456501.html>.

Shi, M., Svensson, J., 2006. Political budget cycles: do they differ across countries and why? J. Public Econ. 90, 1367-1389.

Sutherland, A., 1997. Fiscal crises and aggregate demand: can high public debt reverse the effects of fiscal policy? J. Public Econ. $65,147-162$.

Tagkalakis, A., 2009. Fiscal adjustments: do labor and product market institutions matter? Public Choice 139, 389-411.

Tagkalakis, A., 2011a. Fiscal policy and financial market movement. J. Bank. Finan. 35 (1), 231-251.

Tagkalakis, A., 2011b. Fiscal adjustments and asset price changes. J. Macroecon. 33 (2), 206-223.

Tagkalakis, A., 2012. Fiscal policy and asset price volatility. Empirica 35, 123-156.

Tujula, M., Wolswijk, G., 2007. Budget balances in OECD countries: what makes them change? Empirica 34, 1-14. 